\title{
Blind Seed Disease
}

United States

Department of

Agriculture

Agricultural

Research

Service

Miscellaneous

Publication

Number 1567

November 2001 



\section{Historic, archived document}

Do not assume content reflects current scientific knowledge, policies, or practices. 

Agricultural

Research

\section{Service}

Miscellaneous

Publication

Number 1567
Stephen C. Alderman 


\section{Abstract}

Alderman, Stephen C. 2001. Blind Seed Disease. United States Department of Agriculture, Agricultural Research Service. Miscellaneous Publication No. 1567. $36 \mathrm{pp}$.

In blind seed disease, unfertilized or developing seed of susceptible grasses are colonized by the fungus Gloeotinia temulenta. Infection results in loss of seed germination. About 56 species of grasses are susceptible, including important forage and turf grasses such as ryegrass and tall fescue. The disease occurs in all areas of production of cool season grasses grown for seed. Germination in infected seed samples has been reported as low as 1 percent in New Zealand, 13 percent in the United States, and 50 percent in Great Britain. Blind seed disease continues to periodically plague growers in New Zealand, and a recent reappearance of blind seed in the United States has renewed interest in the disease. This monograph provides a comprehensive review of our understanding of $G$. temulenta and blind seed disease, including host and geographical distribution, taxonomy, biology, and control.

Keywords: Disease management, disease distribution, Gloeotinia, grass seed, host range, seed production, seed quality

This publication reports research involving pesticides. It does not contain recommendations for their use nor does it imply that uses discussed here have been registered. All uses of pesticides must be registered by appropriate state or Federal agencies or both before they can be recommended.

Mention of trade names, commercial products, or companies in this publication is solely for the purpose of providing specific information and does not imply recommendation or endorsement by the U.S. Department of Agriculture over others not recommended.

While supplies last, single copies of this publication can be obtained at no cost from USDA-ARS, National Forage Seed Production Research Center, 3450 S.W. Campus Way, Corvallis, OR 97331.
Copies of this publication may be purchased from the National Technical Information Service, 5285 Port Royal Road, Springfield, VA 22161; telephone (703) 605-6000.

The U.S. Department of Agriculture (USDA) prohibits discrimination in all its programs and activities on the basis of race, color, national origin, sex, religion, age, disability, political beliefs, sexual orientation, or marital or family status. (Not all prohibited bases apply to all programs.) Persons with disabilities who require alternative means for communication of program information (Braille, large print, audiotape, etc.) should contact USDA's TARGET Center at (202) 720-2600 (voice and TDD).

To file a complaint of discrimination, write USDA, Office of Civil Rights, Room 326-W, Whitten Building, 1400 Independence Avenue, SW, Washington, D.C. 20250-9410 or call (202) 720-5964 (voice and TDD). USDA is an equal opportunity provider and employer. 


\section{Contents}

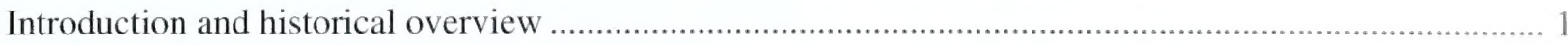

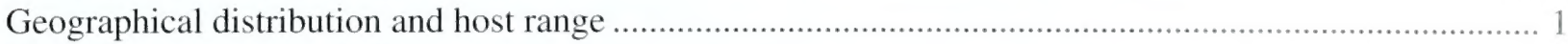

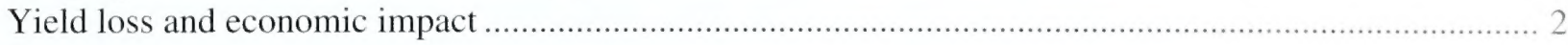

Symptoms …

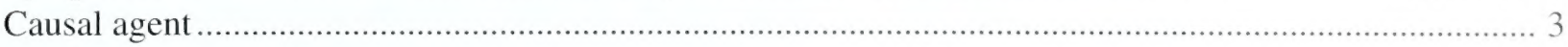

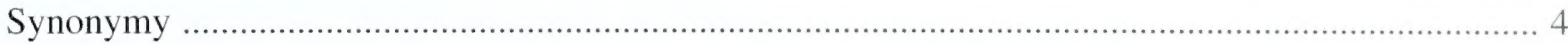

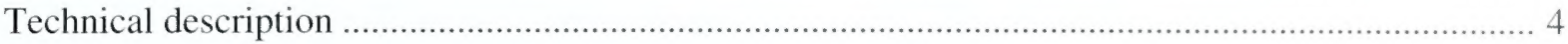

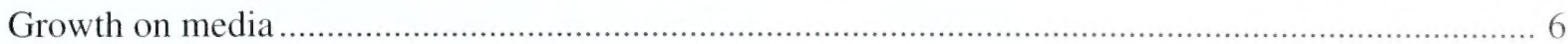

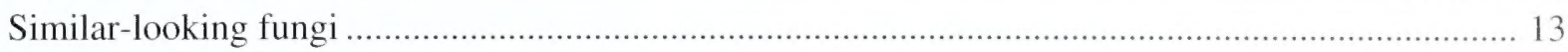

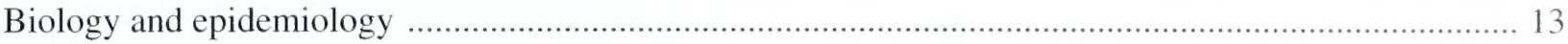

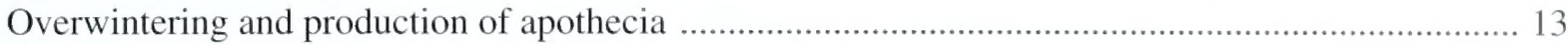

Production and release of ascospores and primary infection ................................................... 13

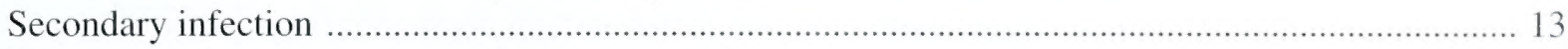

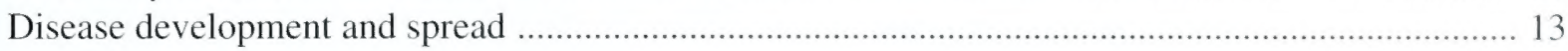

Histopathology

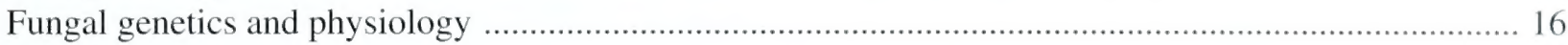

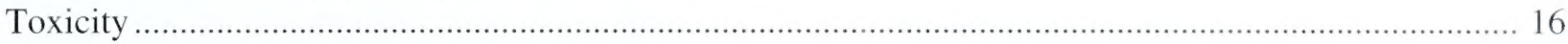

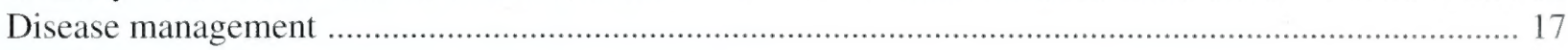

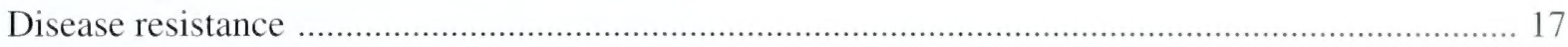

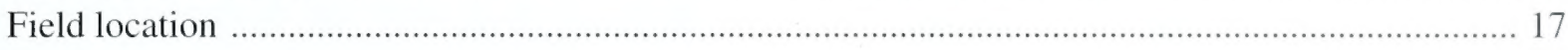

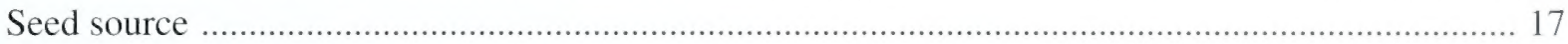

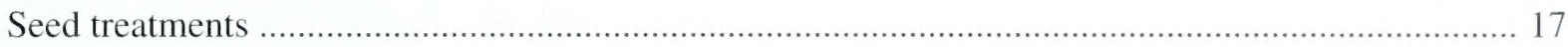

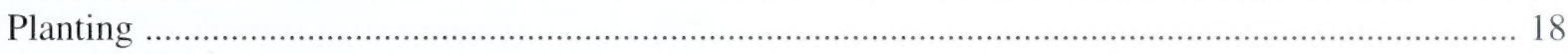

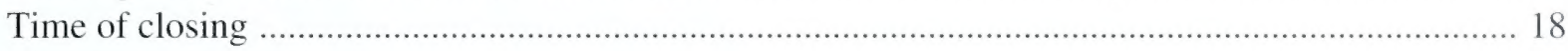

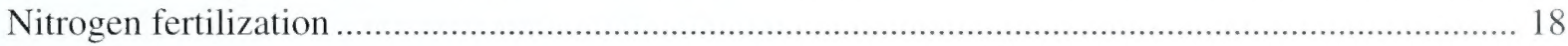

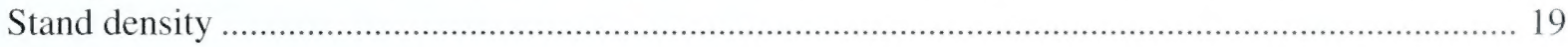

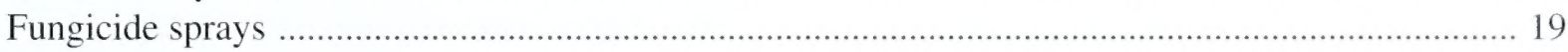

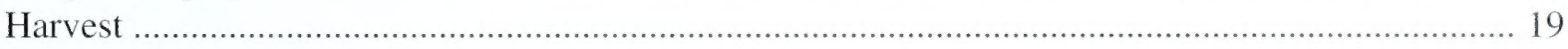

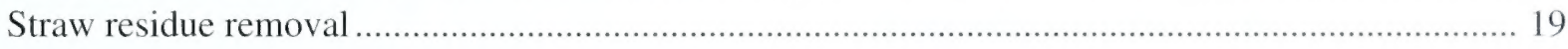

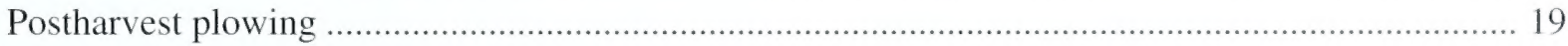

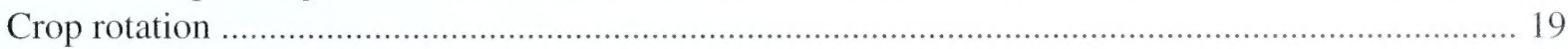

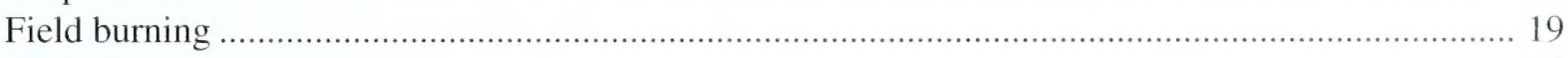

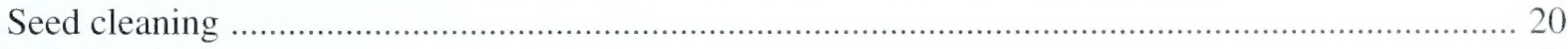

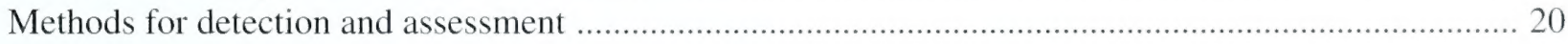

Postharvest disease detection and assessment ........................................................................... 20

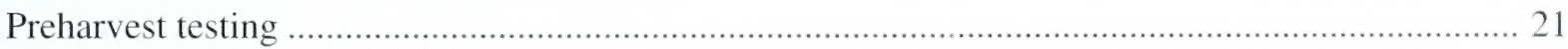

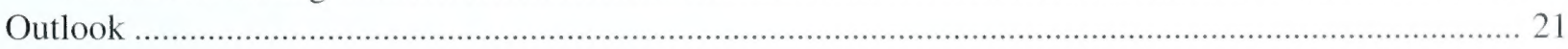

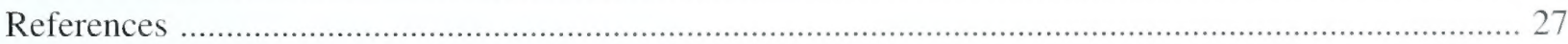

\section{Tables}

Table 1. Geographical and host distribution of Gloeotinia temulenta ................................................. 22

Table 2. Relative susceptibility of grass species to Gloeotinia temulenta ............................................ 24 



\section{Introduction and Historical Overview}

During the early 1920s, growers of perennial ryegrass (Lolium perenne L.) seed in New Zealand were troubled by poor germination of their seed crops. A systematic inquiry initiated in 1923 associated reduced germination with humid conditions during seed development (Foy 1927), but the cause was unknown. By 1926, germination was as low as 19 percent, and in the southern region of New Zealand 95 percent of the seed lots tested had germination of 90 percent or less (Foy 1927). Ungerminable seed had an abnormal appearance characterized by opacity, roughness, and a reddish caryopsis surface (Hyde 1932). These symptoms were difficult to see unless the lemma and palea, which cover the caryopsis, were removed. The difficulty in visual detection of the ungerminable (diseased) seeds led Neill and Hyde (1939) to propose "blind seed" as the common name of the disease.

By 1932, it was apparent that a conidia-producing fungus was associated with affected seeds (Hyde 1932), but it was not until 1937 that pathogenicity of the blind seed fungus (tentatively identified as a Pullularia sp.) was established (Hyde 1937). However, another fungus, distinct from Pullularia, was also found associated with infected seed. After careful study, this second fungus, not Pullularia, was found to cause blind seed disease (Muskett and Calvert 1940 , Wilson et al. 1940).

In 1942, after an investigation of the life history of the blind seed fungus, Neill and Hyde (1942) determined that a fungus called Phialea temulenta Prill. \& Delacr. was identical to the blind seed fungus on ryegrass in New Zealand. P. temulenta was previously reported on seed of rye (Secale cereale L.) in France in 1891 (Prillieux and Delacroix 1891, 1892b). In 1945, Wilson et al. (1945) reviewed the taxonomic placement of $P$. temulenta and erected a new genus, Gloeotinia, to accommodate it. Thus the blind seed fungus became Gloeotinia temulenta (Prill. \& Delacr.) M. Wilson, Noble, \& E.G. Gray.

The effects of blind seed disease on the production of grass seed can be tremendous. Germination in infected seed samples has been as low as 1 percent in New Zealand (Greenall 1943), 13 percent in the United States (Hardison 1945), and 50 percent in Great Britain (Noble and Gray 1945). Blind seed continues to periodically plague growers in New Zealand (Skipp and Hampton 1996), and its recent reappearance in the
United States (Alderman 1996) has renewed interest in the disease here. This monograph provides a comprehensive review of our understanding of $G$. temulenta and blind seed disease, including host and geographical distribution, taxonomy, biology, and control.

\section{Geographical Distribution and Host Range}

The blind seed fungus was first recorded on infected seeds of rye (Secale cereale L.) in France in 1891 (Prillieux and Delacroix 1891, Neill and Hyde 1942). Although first reported on rye, its subsequent occurrence on this crop is very rare. Blind seed disease is primarily a problem of forage and turf grasses grown for seed.

Blind seed disease was unknown in Great Britain until after its discovery in New Zealand. However, the connection between blind seed and low germination in ryegrass (Lolium sp.) was suspected to be of long standing in Great Britain, since low germination in some years was well known (Calvert and Muskett 1944, 1945). Proof of the long-standing occurrence of blind seed was established when conidia of $G$. temulenta were found among stored seeds from a 1909 ryegrass crop grown in Ireland (Lafferty 1948). The identification of blind seed disease in the United States in 1944 established that the fungus was widely distributed on ryegrass grown for seed, a distribution likely established through the international grass seed trade.

Blind seed has been reported from Australia, including Tasmania, Victoria, and New South Wales (Neill and Hyde 1939, Wade 1949, Anonymous 1955, Wade 1957, Anonymous 1962, McGee 1971a, Munro 1978); Denmark (Noble 1939, Gemmell 1940, Lafferty 1948, Kristensen and Jørgensen 1960); England, including Kent, Sussex, Hereford, and the Isle of Man (Neill and Hyde 1939, Gemmell 1940, Glasscock 1940); Ireland (Gemmell 1940, Lafferty 1948); France (Prillieux and Delacroix 1891, 1892a); The Netherlands (de Tempe 1950, 1966); New Zealand (Gorman 1939; Neill and Hyde 1939; Blair 1947, 1948; Latch 1966; Hampton and Scott 1980a); Northern Ireland (Neill and Hyde 1939; Gemmell 1940; Calvert and Muskett 1944. 1945); Scotland, including Ayrshire and the Shetland Islands (Neill and Hyde 1939, Gemmell 1940, Noble and Gray 1945, Dennis and Gray 1954); Sweden (Neill and Hyde 1939); United States, including 
Oregon (Fischer 1944, Hardison 1945, Alderman 1988); and Wales (Neill and Hyde 1939).

Worldwide, 56 host species have been reported as susceptible to G. temulenta (table 1). Most hosts are in the subfamily Pooideae, tribes Avenae and Poeae, with heaviest infections reported in the genera Agrostis, Festuca, Lolium, and Poa (Hardison 1962) (table 2). Lolium perenne is widely recognized as susceptible and has been identified as a host from all countries reporting blind seed disease. In the Triticeae, moderate to heavy infections were observed on Psathyrostachys, Pseudoroegneria, and Secale species. Grasses in the Bromeae appear less susceptible, with little to no infection observed among species of Bromus.

In the United States, blind seed disease was found on species of Agrostis, Aira, Alopecurus, Bromus, Cynosurus, Deschampsia, Danthonia, Festuca, Glyceria, Hordeum, Holcus, Lolium, Phleum, and Poa (table 1). Despite the susceptibility of many common grasses in the United States, G. temulenta has been reported only from Oregon. In New Zealand, blind seed was reported on Agrostis, Cynosurus, Festuca, Holcus, Lolium, Poa, and Secale cereale. In Northern Ireland, blind seed was found on Agrostis, Cynosurus, Festuca, Holcus, Lolium, and Poa. Additional host reports include Calamagrostis from Germany, Elytrigia from Norway, and Secale from France and Germany.

Most of these U.S. hosts were reported in a comprehensive host range study by Hardison (1962) (tables 1 and 2). However, there is one discrepancy in the U.S. host range. Fischer (1944) reported $G$. temulenta on Danthonia californica Boland (subfamily Arundinoideae, tribe Danthoneae). Hardison (1962), however, did not observe infection on $D$. californica inoculated with $G$. temulenta under natural or artificial conditions. Additional studies are needed to determine all grasses that are susceptible to G. temulenta and their relative susceptibility.

\section{Yield Loss and Economic Impact}

In the production of grass seed, loss from blind seed disease occurs through a reduction in germinable seed since infected seeds are ungerminable. In addition, seed lots with germination below certification limits, or below seed contract standards, are of less value and in some countries are unmarketable. Presence of $G$. temulenta in import seed shipments may result in rejection of the seed by some countries (HalfonMeiri 1978).

Australia. Blind seed was reported to cause few crop failures, although in 1969, 2,400 out of 9,000 acres could not be certified because of blind seed disease (McGee 1971a).

Denmark. A low level of blind seed was found in 6 percent of ryegrass samples exported from Denmark to Ireland (Lafferty 1948). A low level of blind seed was also found in 1957 (Kristensen and Jørgensen 1960).

England. In 1938 and 1939, germination as low as 50 percent was common in ryegrass (Noble and Gray 1945). In 1940, an average of 26 percent of ryegrass seed from south England was infected (Gemmell 1940).

The Netherlands. In 1965, the level of infection with the blind seed fungus ranged from 0 to 94 percent, with an average infection rate of 19.2 percent (de Tempe 1966).

Scotland. In 1938-1939, infection of ryegrass seed as great as 50 percent was reported (Gemmell 1940, Noble and Gray 1945). Average infection in samples from Ayrshire was 26.4 percent (Gemmell 1940).

New Zealand. Between 1931 and 1934, cost of seed lost to blind seed was estimated at £1,975-4,382 (Gorman 1939). In 1938, average germination of ryegrass was 67-76 percent in Christchurch, Canterbury, and South Canterbury (Hyde 1938b). Greenall (1943) reported germination of ryegrass as low as 1 percent. Greenall also noted that the severity of blind seed disease depended on environmental conditions, and he expected that in South Otago one year in every two or three would be accompanied by poor germination. During 1944-1946, 45-84 percent of samples from the South Island had more than 20 percent blind seed and 10-22 percent of samples had 70-100 percent diseased seed (Blair 1947). Stocks of seed throughout New Zealand had germination below 40 percent - in some lots as low as 5 percent (Osborn 1947). In seed exported from New Zealand to Ireland, 26 percent of samples had a low level of blind seed disease (Lafferty 1948). 
Between 1948 and 1960, 70 percent of seed samples tested positive for blind seed disease; the average was 12 percent (Hampton and Scott 1980a). Levels of infection declined after 1960. During 1976-1978, 27 percent of samples tested positive, with a mean of 4 percent infected seed. The disease declined between 1964 and 1974 to the point that preharvest testing was stopped (Scott 1974). Hampton and Scott (1980a) related decreased levels of blind seed to the increased use of nitrogen fertilizers. In 1980-1990, only low levels of blind seed were detected (Skipp and Hampton 1996). In 1993, environmental conditions were favorable for blind seed development, and 100 percent of seed lots were infested, with a mean of 13.5 percent infected seed (Skipp and Hampton 1996). Low levels of blind seed infection returned in 1995 when conditions were again less favorable for blind seed development (Skipp and Hampton 1996).

Northern Ireland. By 1944, infection levels ranged from 31 to 55 percent and were as high as 70 percent in perennial ryegrass (Calvert and Muskett 1944). During 1947-1948, 60-70 percent of samples had trace to 60 percent infected seeds (Lafferty 1948).

United States. In the Willamette Valley of Oregon, low germination in ryegrass was first noticed in 1941 (Hardison 1957). Blind seed disease was positively identified in 1943 (Hardison 1948, 1949). By 1944, the disease was found in 85 percent of certified samples (Hardison 1945), and about one-quarter of the seed crop could not be certified (Hardison 1948).

U.S. levels of infection with blind seed disease declined during the late 1940s after the introduction of field burning to control the disease (Hardison 1976, 1980). During the 1950 s, blind seed increased as growers explored alternatives to field burning. During the 1960 s, when field burning was again widely practiced, blind seed occurrence returned to trace levels. Low levels of the disease were detected during 1986-1989 (Alderman 1991a,b).

In 1991, the Oregon State legislature mandated an incremental reduction in postharvest burning of grass fields to a maximum of 16,000 hectares after 1997. The area burned declined from about 80,000 hectares in 1987 to about 28,000 in 1993 (Young et al. 1994). In 1995, a high level of blind seed (20 percent infected seeds) was found in several fields of tall fescue in Oregon (Alderman 1996). However, surveys from 1995-1997 (Alderman 1999) indicate that blind seed disease levels in most fields in Oregon remain low.

\section{Symptoms}

The seed is the only component of the host plant infected by G. temulenta (Wilson et al. 1945). Infected caryopses appear shriveled, rough on the surface, and rusty brown or pinkish in color (Gemmell 1940, Calvert and Muskett 1945, Hyde 1945, Noble and Gray 1945, Wilson et al. 1945, Blair 1947). Conidia accumulate on the seed surface in a spore secretion (slime), which may be waxy and clear or pale pink in color (Hyde 1938a) or may appear as a reddish-brown crust (Calvert and Muskett 1945, Hyde 1945). Healthy caryopses normally appear golden brown, plump, and smooth (Calvert and Muskett 1945). However, infected seeds covered by the lemma and palea are difficult to discern from normal seeds (Gemmell 1940. Neill and Hyde 1942, Hyde 1945).

A consequence of blind seed infection is reduced germination, and the correlation between percentage of infected seed and percentage germination in ryegrass is well established (Hyde 1932; Gemmell 1940; Greenall 1943; Calvert and Muskett 1944. 1945; Hyde 1945; Lafferty 1948; Chestnutt 1958; Hardison 1963; de Tempe 1966; Matthews 1980). Germination of infected seed is rarely greater than 10 percent (Gemmell 1940, Lafferty 1948).

\section{Causal Agent}

The taxonomic placement of Gloeotinia is not clearly established. Wilson et al. (1954) placed G. temulenta within the family Sclerotiniaceae, based on its occurrence as a plant pathogen, presence of spermatia and macroconidia, and formation of a fleshy cupulate apothecium from a stroma. Although G. temulenta shares many features of the Sclerotiniaceae, it develops only an interwoven mycelium within the infected seed and does not form the true sclerotium that is characteristic of the Sclerotiniaceae. Ellis (1956) described Gloeotinia as structurally similar to Symphyosirinia, a member of the family Leotiaceae. Similar views were stated by Baral (1994) who considered Gloeotinia and Symphyosirinia related and members of the Leotiaceae, subfamily Hymenoscyphoideae. In 1997, Holst-Jensen et al. (1997) provided data from DNA analysis that Gloeotinia was distinct from other fungi within the Sclerotiniaceae. These studies support the concept that Gloeotina should be considered a member of the Leotiaceae, subfamily Hymenoscyphoideae.

Schumacher (1979) reported that a specimen described on Bromus erectus by Quelet (1883) as 
Phialea granigena was conspecific with $G$. temulenta and therefore represented an older name of the fungus. Alderman (1997) recognized G. temulenta and $G$. granigena as separate species, based on host range and morphological differences. Bromus erectus is not believed to be a host for G. temulenta (Hardison 1962, Alderman 1997). Little is known about G. granigena. Additional studies concerning species identity and their associated host range in the genus Gloeotinia are needed. Unfortunately, specimens of Gloeotinia from outside areas of commercial seed production are very rare in nature.

Two other species of Gloeotinia from Germany have been described: G. aschersoniana (P.C. Hennings and T. Ploettner) H.O. Baral on Carex and G. juncorum (J. Velenovsky) H.O. Baral on Juncus (Baral and Krieglsteiner 1985). Nothing is known of the life history of these species.

\section{Synonymy}

\section{Teleomorph:}

Gloeotinia temulenta Prill. \& Delacr. (Wilson et al. 1954)

Phialea temulenta Prill. \& Delacr. (Prillieux and Delacroix 1892b)

Peziza (Phialea) temulenta Prill. \& Delacr. (Prillieux and Delacroix 1892a)

Ciboria (Stromatinia) temulenta Prill. \& Delacr. (Prillieux and Delacroix 1893)

Stromatinia temulenta Prill. \& Delacr. (Prillieux 1897)

Sclerotinia secalincola Rehm (Rehm 1900)

Sclerotinia temulenta (Prill. and Delacr.) Rehm (Höhnel 1903)

Stromatinia secalincola (Rehm) Boudier (Boudier 1907)

Phialea mucosa Gray (Gray 1942)

Gloeotinia granigena (Q.) Schumacher for hosts other than Bromus (Alderman 1997)

\section{Anamorph:}

Endoconidium temulentum Prill. and Delacr. (Prillieux and Delacroix 1891)

\section{Technical Description}

Stroma. Infection of the grass caryopsis results in the mummification of the caryopsis, creating a substratal stroma (Spooner 1987, Williams and Spooner 1991). Hyphae, 3-4 $\mu \mathrm{m}$ wide, ramify throughout the pericarp, teste, and endosperm and are not differentiated into rind and medullary parenchyma (Gray 1942,
Wilson et al. 1945). A true sclerotium does not develop, although the infected seed functions similarly to a sclerotium as a means of survival through the winter.

Sporodochia. In late winter or early spring, pinkish, pulvinate, gelatinous sporodochia form either on the surface of the pales or between the pales and caryopsis (Neill and Hyde 1939, Gray 1942, Calvert and Muskett 1945, Griffiths 1959b). They are 0.4-1 3 0.5-1.5 mm in size (Prillieux 1897, Neill and Hyde 1939, Gray 1942, Calvert and Muskett 1945). Sporodochia consist of a core of closely septate, branching hyphae (Neill and Hyde 1939, Griffiths 1959 b) with the terminal cells of each branch bearing 1-4 microconidiophores (Gray 1942, Griffiths 1959b).

Microconidiophores and microconidia (spermatia). Microconidiophores are 2-5 $\mu \mathrm{m}$ in diameter and 5-9 $\mu \mathrm{m}$ long, septate, guttulate, hyaline, and penicillate (branched 2 or 3 times) (Neill and Hyde 1939, Gray 1942, Griffiths 1959b). Microconidia are first formed by a constriction below the apex of the microconidiophore. The rest bud off in succession inside a tube formed by the terminal portion of the microconidiophore (Prillieux and Delacroix 1892b; Neill and Hyde 1939; Gray 1942; Wilson et al. 1945, 1954; Griffiths 1959b).

Microconidia are unicellular, uninucleate, ovoid, guttulate or biguttulate, hyaline, 1.8-3.0 3 2.3-6.0 $\mu \mathrm{m}$ (Gray 1942, Calvert and Muskett 1945, Griffiths 1959b). In microconidial germination, a terminal germ tube forms; or if a transverse septum forms, a terminal or lateral germ tube will be produced (Griffiths 1959b).

\section{Macroconidiophores and macroconidia.}

Macroconidiophores are short barrel-shaped cells, 2-3 $\mu \mathrm{m}$ wide and 5-15 $\mu \mathrm{m}$ long, that arise laterally on the hyphae (Neill and Hyde 1939, Griffiths 1959b). Macroconidia are budded from the apex of the macroconidiophores (Griffiths 1959b) (figure 1) and arrange in clusters perpendicular to the hypha (Calvert and Muskett 1945, Wilson et al. 1945). Up to 30 macroconidia develop per conidiophore (Wilson et al. 1945).

Macroconidia are smooth, unicellular, uninucleate, hyaline, cylindrical to slightly cresentric with rounded ends, and usually biguttulate (figure 2) (Gray 1942; Calvert and Muskett 1945; Wilson et al. 1945, 1954; Spooner 1987). They are 2.5-6 $311-21 \mu \mathrm{m}$ in size. 


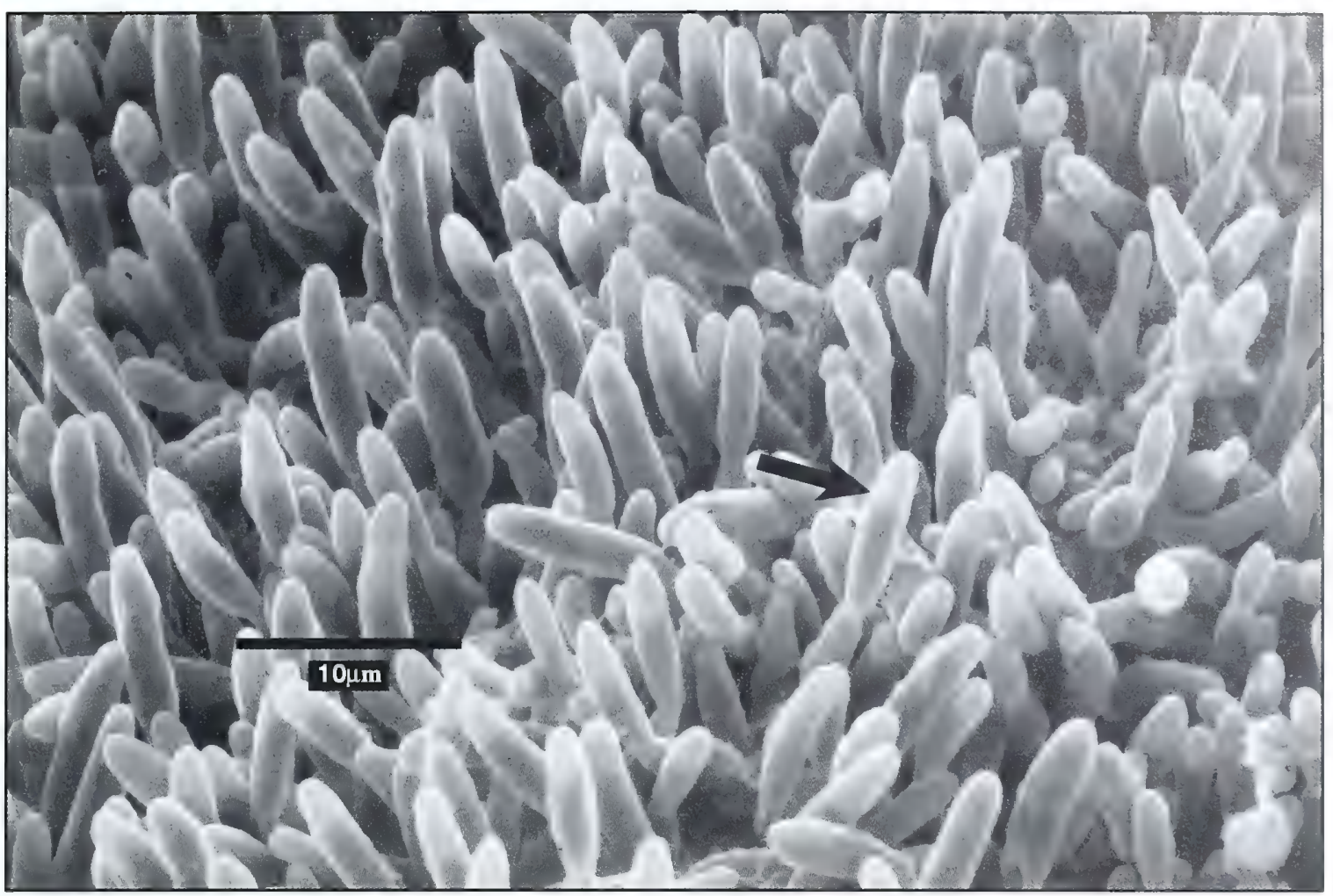

Figure 1. Scanning electron micrograph of conidia of Gloeotinia temulenta being produced on the surface of an infected seed. Arrow points to macroconidium.

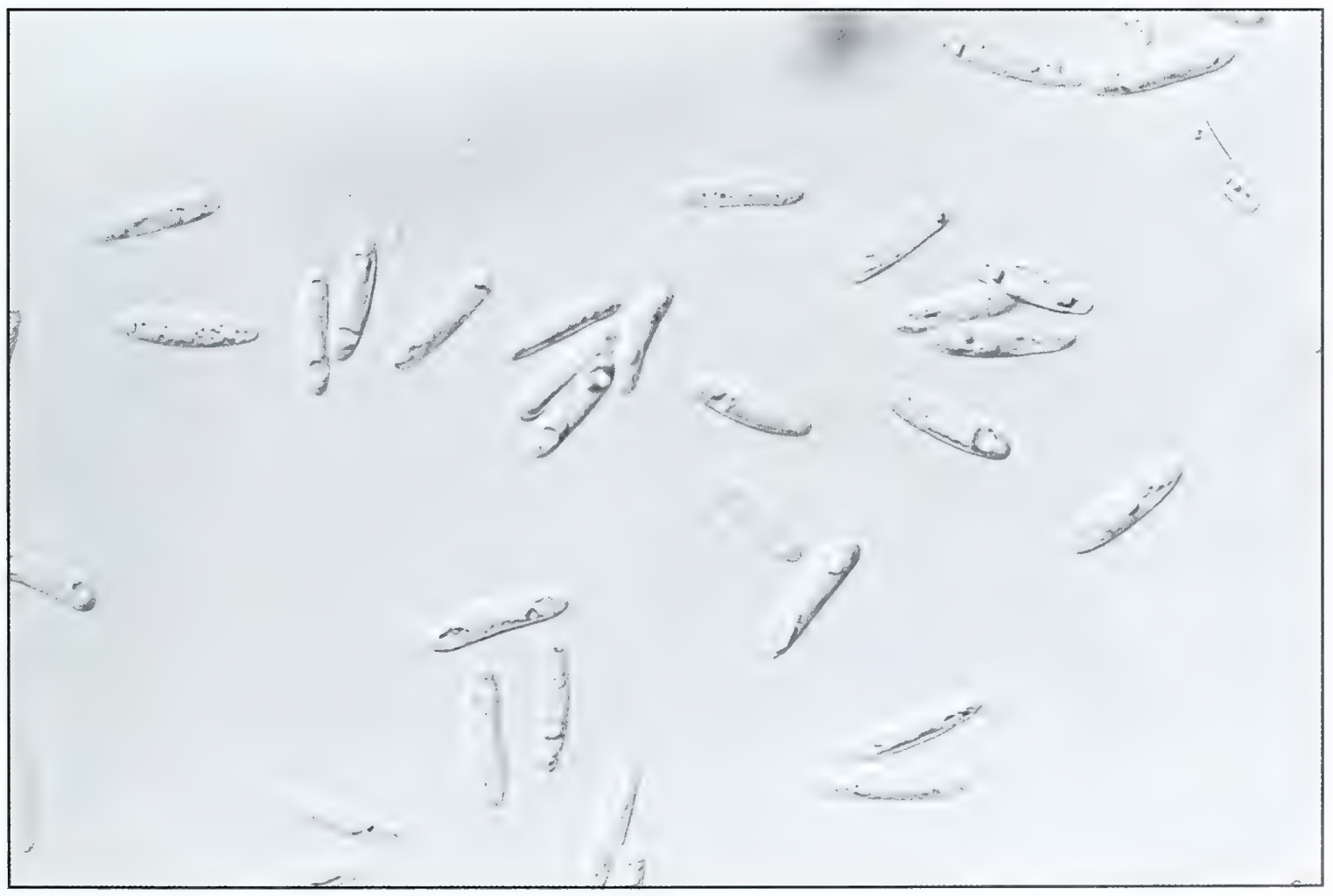

Figure 2. Macroconidia of Gloeotinia temulenta. 
The vegetative nucleus is $3-532 \mu \mathrm{m}$ and the nucleolus may be as large as $2 \mu \mathrm{m}$ (Griffiths 1959b).

On the surface of the caryopsis, macroconidia are embedded in a pinkish, slimy mass (Spooner 1987) that dries to form a hard reddish-brown crust (Calvert and Muskett 1945, Hyde 1945) (figures 3-5). When germinating, macroconidia swell and produce one or two germ tubes (Griffiths 1959b).

Apothecia. Apothecia are small, fleshy, and cupshaped. One to 7 (usually 1 to 3 ) apothecia emerge from each infected seed (Prillieux 1897; Gray 1942; Calvert and Muskett 1945; Wilson et al. 1945, 1954) (figure 6). The stipe is smooth, velutinous under magnification, externally white or gray, internally pinkish brown, enlarging upward (Neill and Hyde 1939), and longitudinally furrowed (Spooner 1987). The stipe varies from 1 to $10 \mathrm{~mm}$ in length and from 0.2 to $0.5 \mathrm{~mm}$ in diameter (Prillieux and Delacroix 1892b, Rehm 1900, Gray 1942, Calvert and Muskett 1945 ) and is composed of hyaline, parallel hyphae, 4$6 \mu \mathrm{m}$ in diameter, occasionally intertwining and seldom branched (Gray 1942, Calvert and Muskett 1945).

Apothecia emerge from the caryopsis and elongate (figure 7). The disk of the apothecium is at first closed (Gray 1942) but opens to cup-shaped and with age becomes saucer-shaped and then flat (Gray 1942, Calvert and Muskett 1945, Spooner 1987) (figures 8 and 9). The disc diameter ranges from 1.0 to $7.0 \mathrm{~mm}$ (Prillieux and Delacroix 1892b, Rehm 1900. Neill and Hyde 1939, Gray 1942, Calvert and Muskett 1945). The disk color changes from light pinkish brown to deep brown (Calvert and Muskett 1945), orange brown (Spooner 1987), or pale pinkish cinnamon, darkening to cinnamon when old (Neill and Hyde 1939, Gray 1942). The margin is smooth and entire (Neill and Hyde 1939, Gray 1942, Calvert and Muskett 1945, Spooner 1987) and is radially wrinkled around the stipe apex (Spooner 1987).

Hymenium. The hymenium is $100-140 \mu \mathrm{m}$ deep (Williams and Spooner 1991). The subhymenium consists of intricately intertwined and coiled hyphae 2.5-3 $\mu \mathrm{m}$ in diameter. The subhymenium blends into the medullary excipulum, a 22-27 $\mu \mathrm{m}$ deep layer composed of fine, densely intertwining hyphae 2-5 um broad (Neill and Hyde 1939, Gray 1942, Williams and Spooner 1991). The outermost layer (the ectal excipulum) is $35-40 \mu \mathrm{m}$ thick and is composed of parallel to somewhat interwoven hyphae 3.5-4.5 $\mu \mathrm{m}$ in diameter (Williams and Spooner 1991) (figure 10).

Asci. The asci are cylindrical and clavate, with 8 spores obliquely placed in a single row (uniseriate) in the upper two-thirds of the ascus (Neill and Hyde 1939, Gray 1942, Calvert and Muskett 1945, Spooner 1987) (figure 11). Ascus size is variable but falls within the range of 66-120 $\mu \mathrm{m}$ long 3 3-8 $\mu \mathrm{m}$ wide. The ascus base tapers to about 2-5 $\mu \mathrm{m}$ (Spooner 1987, Williams and Spooner 1991). The apical cap is 1-3 $\mu \mathrm{m}$ thick (Alderman 1997), and the apical plug does not stain blue with iodine (Prillieux and Delacroix 1892b, Neill and Hyde 1939, Gray 1942, Calvert and Muskett 1945, Wilson et al. 1954, Spooner 1987).

Ascospores. Ascospores are hyaline, smooth, elliptical, fusoid to broadly fusoid, and usually biguttulate (Neill and Hyde 1939, Gray 1942, Calvert and Muskett 1945). One side is often flattened, or curved, continuous, or rarely developing a central septum (Spooner 1987, Williams and Spooner 1991). Ascospore size is variable, 7-14 $32.5-4.5 \mu \mathrm{m}$. Germinating ascospores swell to about $1035 \mu \mathrm{m}$ (Neill and Hyde 1939) (figure 12). The first germ tube is terminal, followed by a second that is frequently lateral in position and usually constricted at the point of origin. They normally develop a central septum and two polar hyphae, but often lack a septum and have a single polar or lateral hypha (Neill and Hyde 1939, Calvert and Muskett 1945)

Paraphyses. Paraphyses are fusiform, hyaline, nonseptate (Neill and Hyde 1939, Gray 1942, Calvert and Muskett 1945) or sparsely septate (Spooner 1987) and 1.5-4 $\mu \mathrm{m}$ wide (Neill and Hyde 1939, Gray 1942). Spooner (1987) described the paraphyses as enlarging at the apex to 2.5-3.0 $\mu \mathrm{m}$, but others (Neill and Hyde 1939, Gray 1942, Calvert and Muskett 1945) reported that the apex was not swollen. Paraphyses are as long as or slightly longer than the asci (figure 13).

\section{Growth on Media}

On a nutrient medium such as potato dextrose agar, $G$. temulenta grows slowly and produces a partly submerged, branching, hyaline, septate mycelium (Neil and Hyde 1939, Calvert and Muskett 1945). Sporulation and slime production occur after 7 days (Calvert and Muskett 1945, Wilson et al. 1945, Hair 1952) and in culture appears reddish brown (Neill and Hyde 1939) or chocolate brown (Wilson et al. 1945). The 


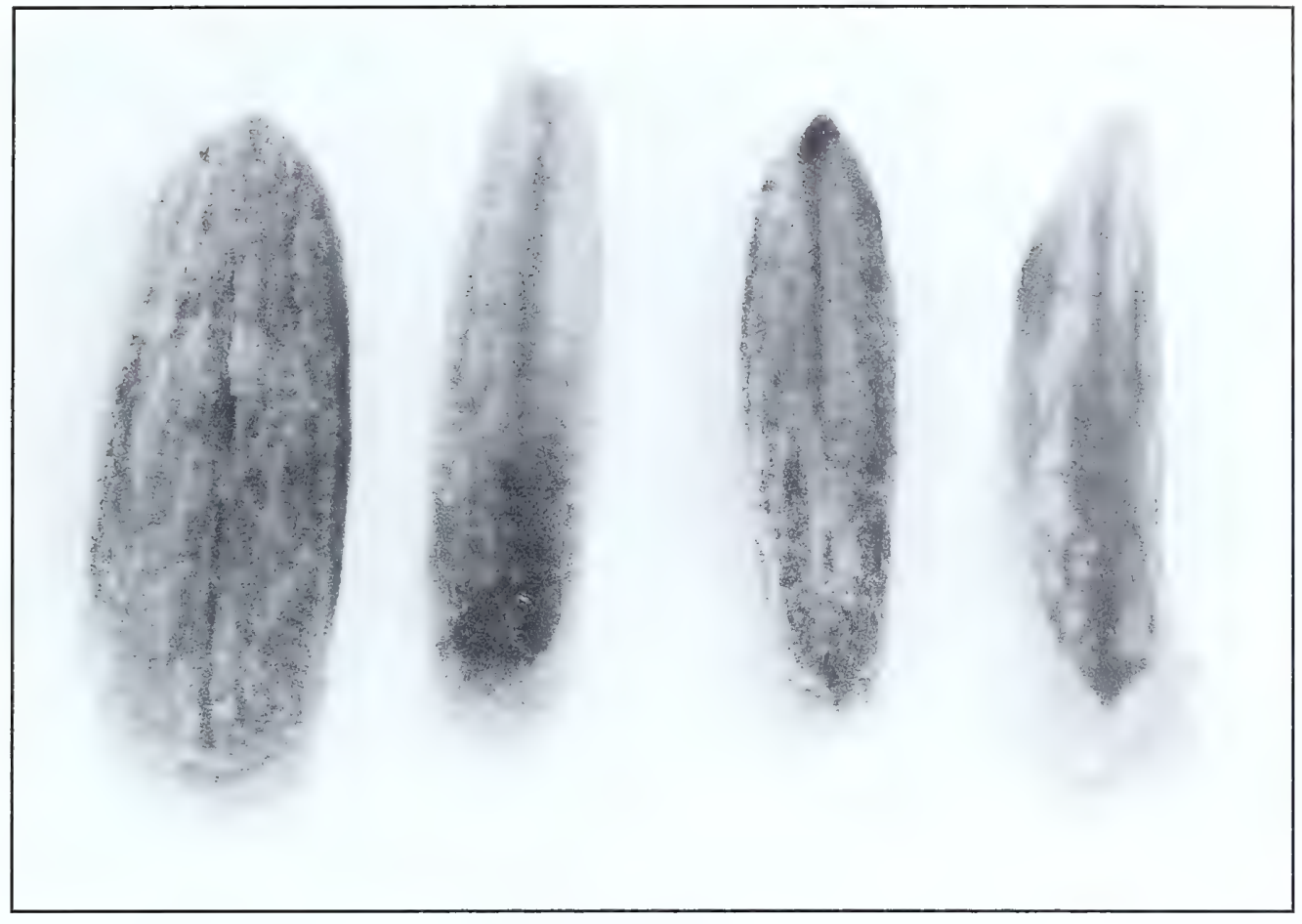

Figure 3. Seeds of Lolium multiflorum infected with Gloeotinia temulenta (lemma and palea removed). Healthy seed is on left.

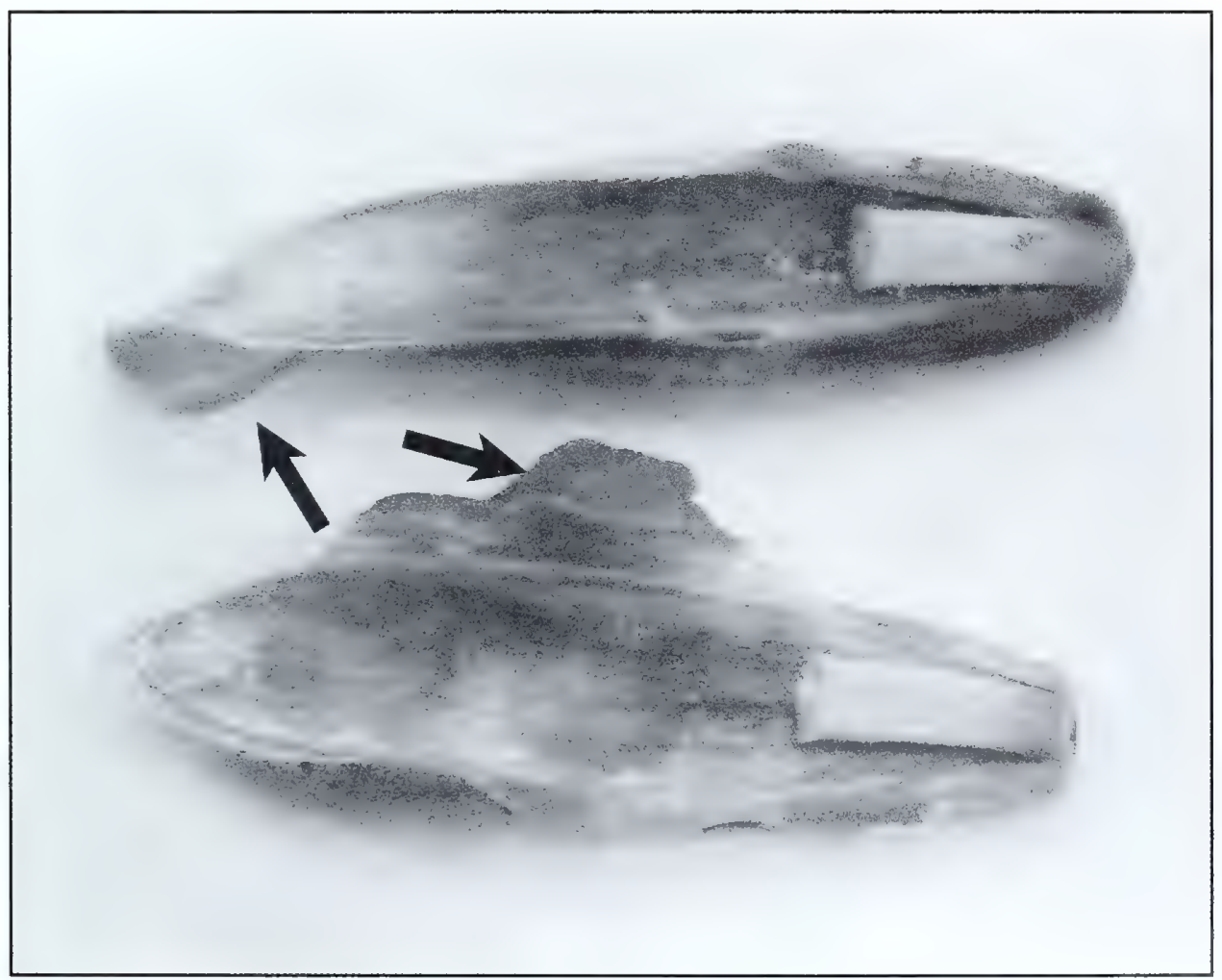

Figure 4. Seeds of Lolium multiflorum infected with Gloeotinia temulenta. Arrow points to conidial slime. 


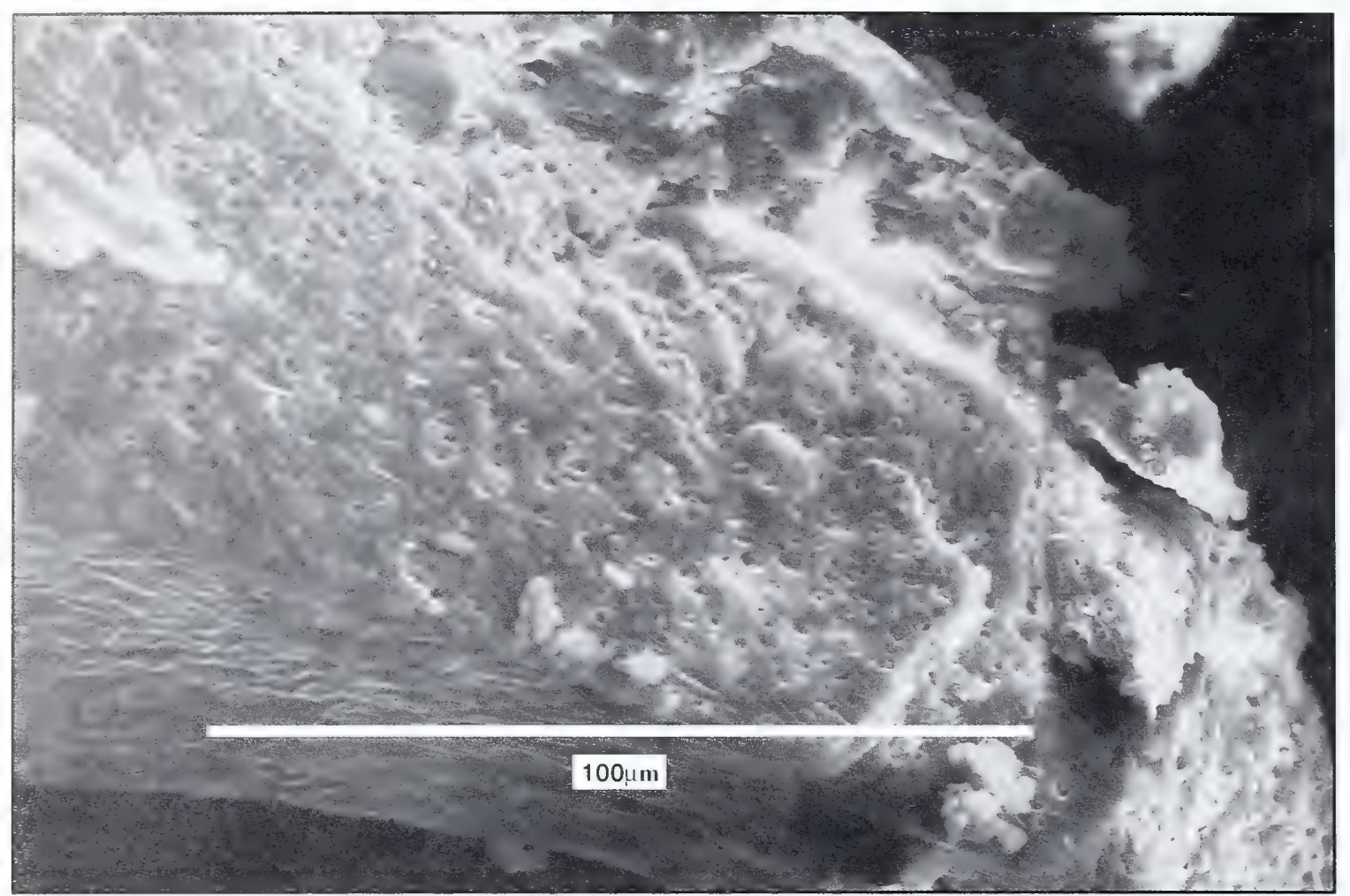

Figure 5. Scanning electron micrograph of the surface of conidial slime of Gloeotinia temulenta.

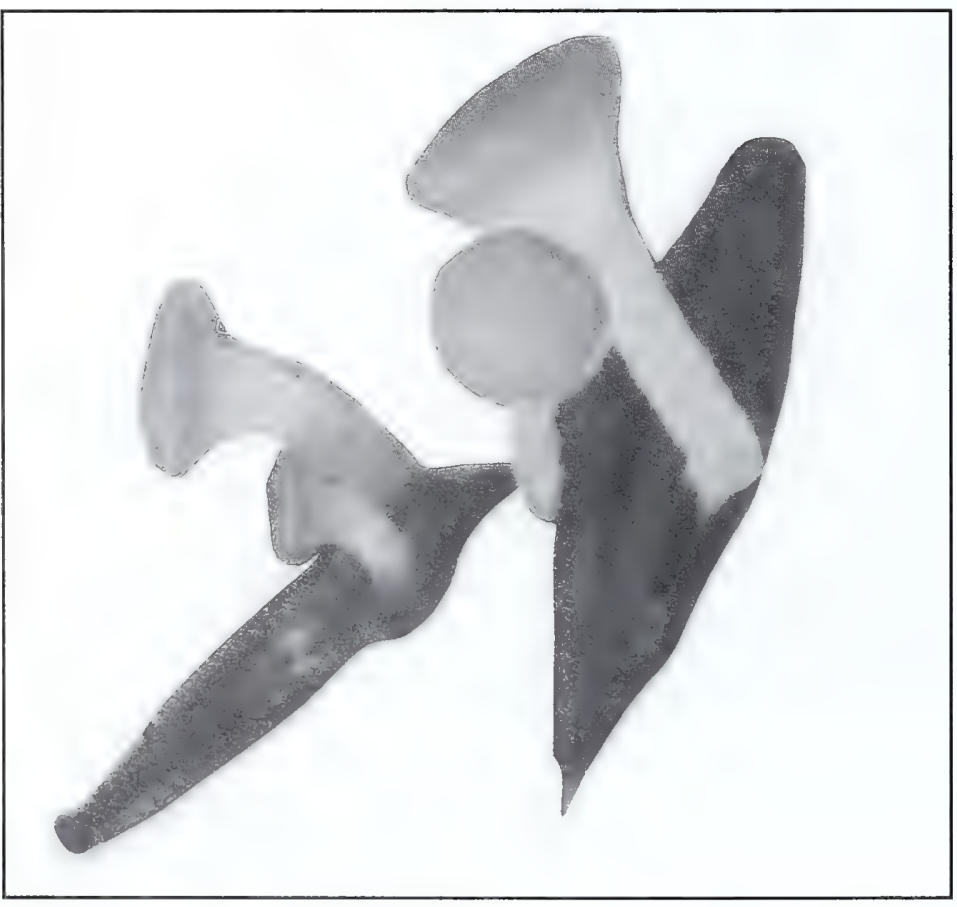

Figure 6. Apothecia of Gloeotinia temulenta. 


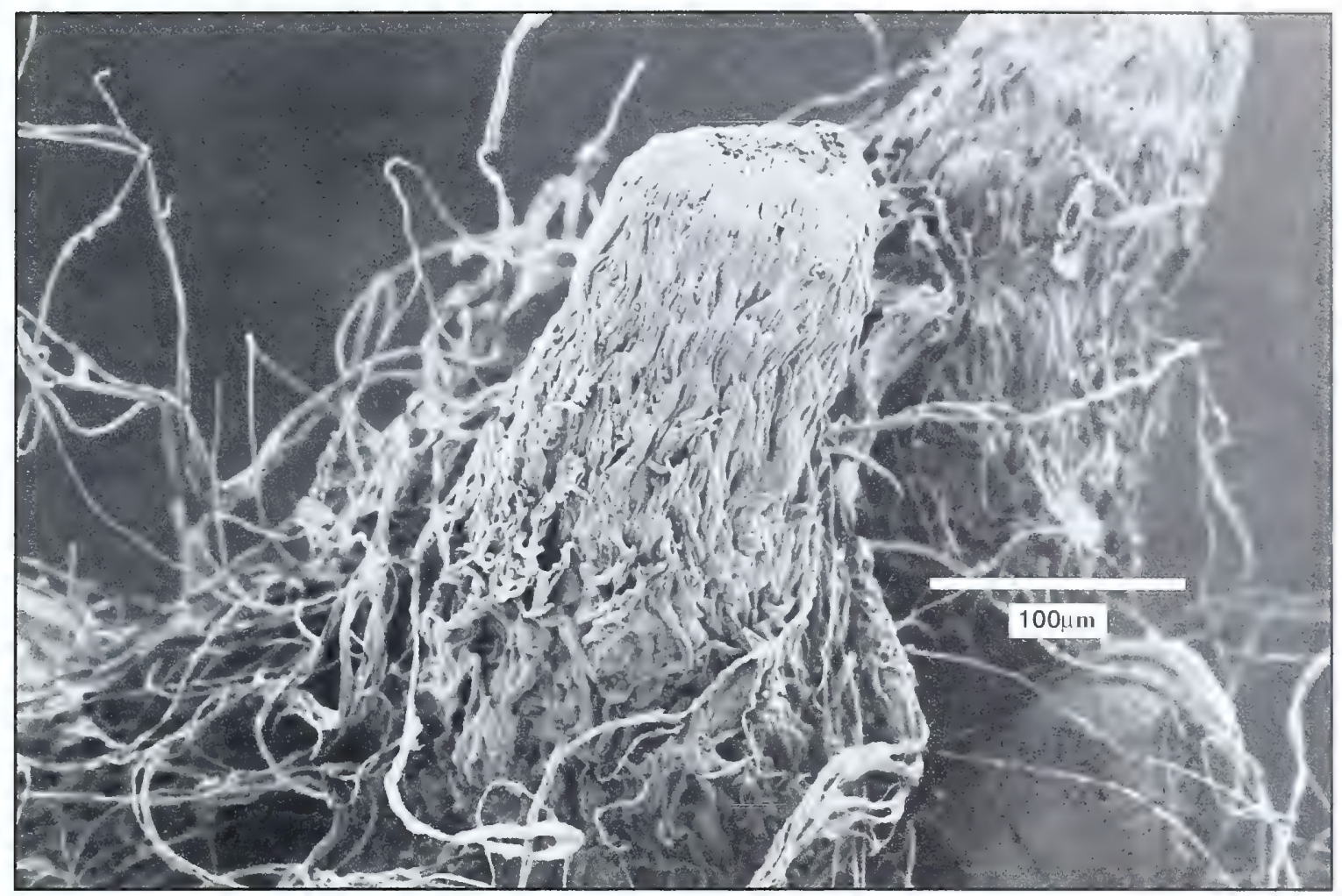

Figure 7. Scanning electron micrograph of the early stage of apothecium development of Gloeotinia temulenta.

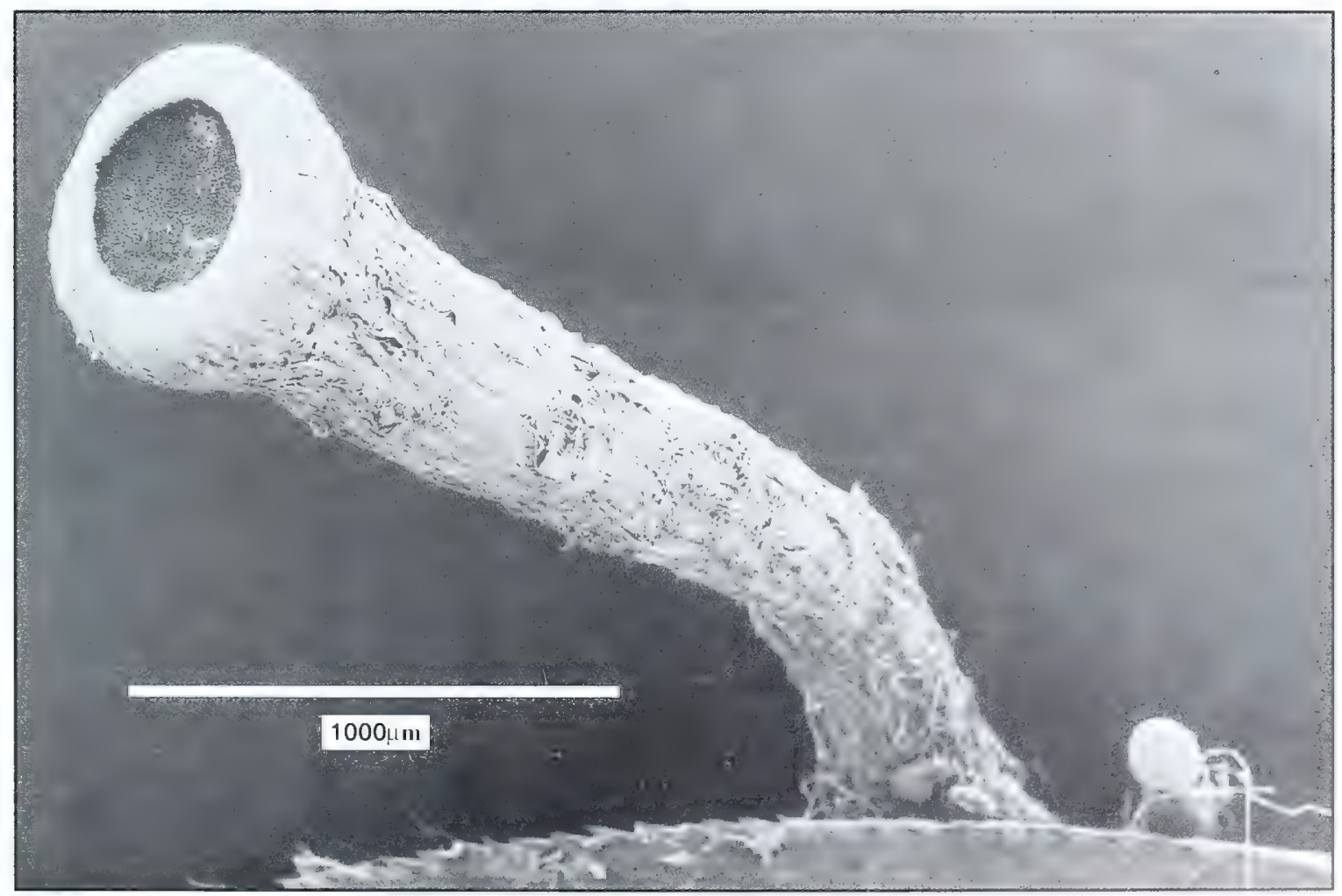

Figure 8. Scanning electron micrograph of developing apothecium of Gloeotinia temulenta. 


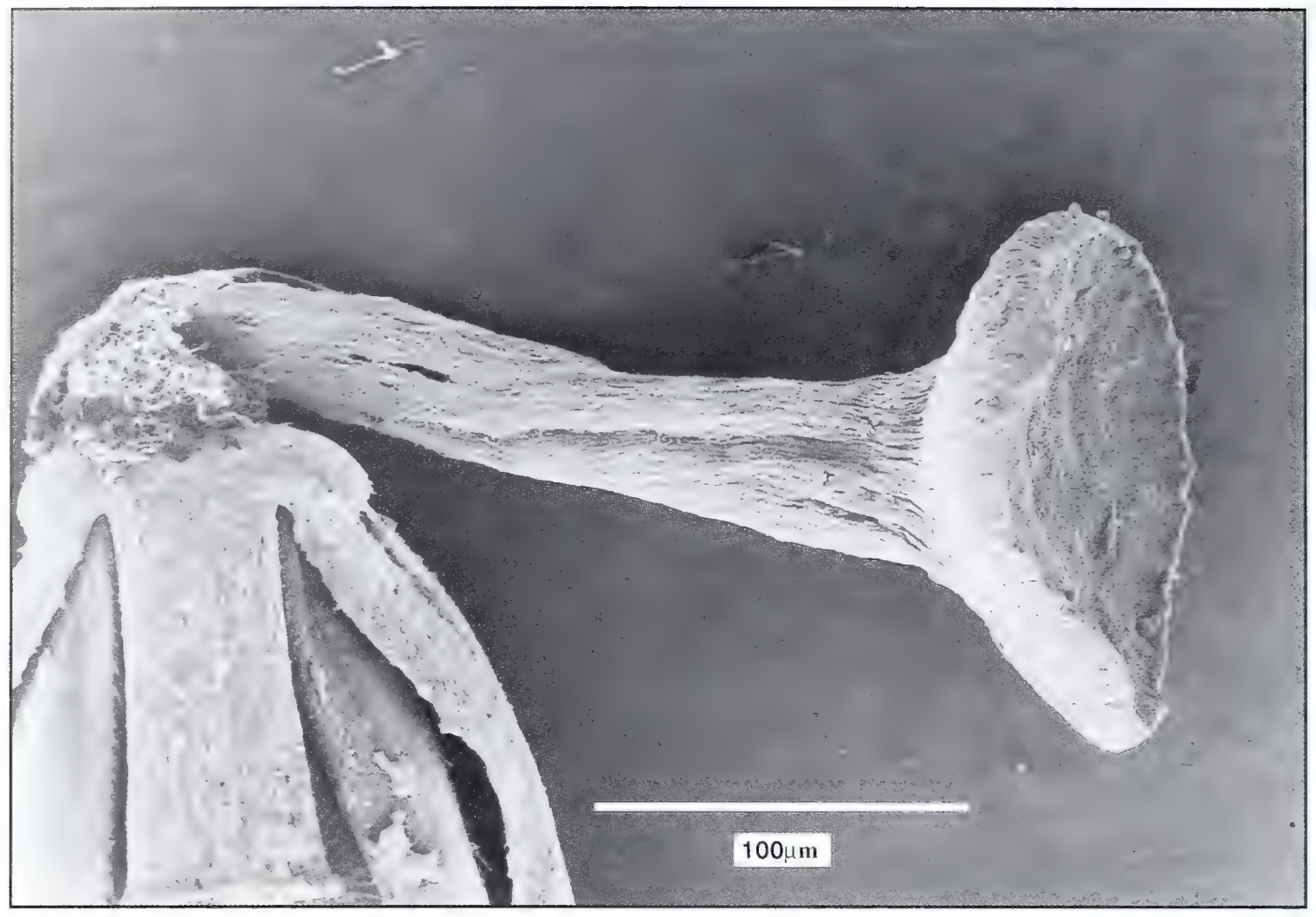

Figure 9. Scanning electron micrograph of mature apothecium of Gloeotinia temulenta.

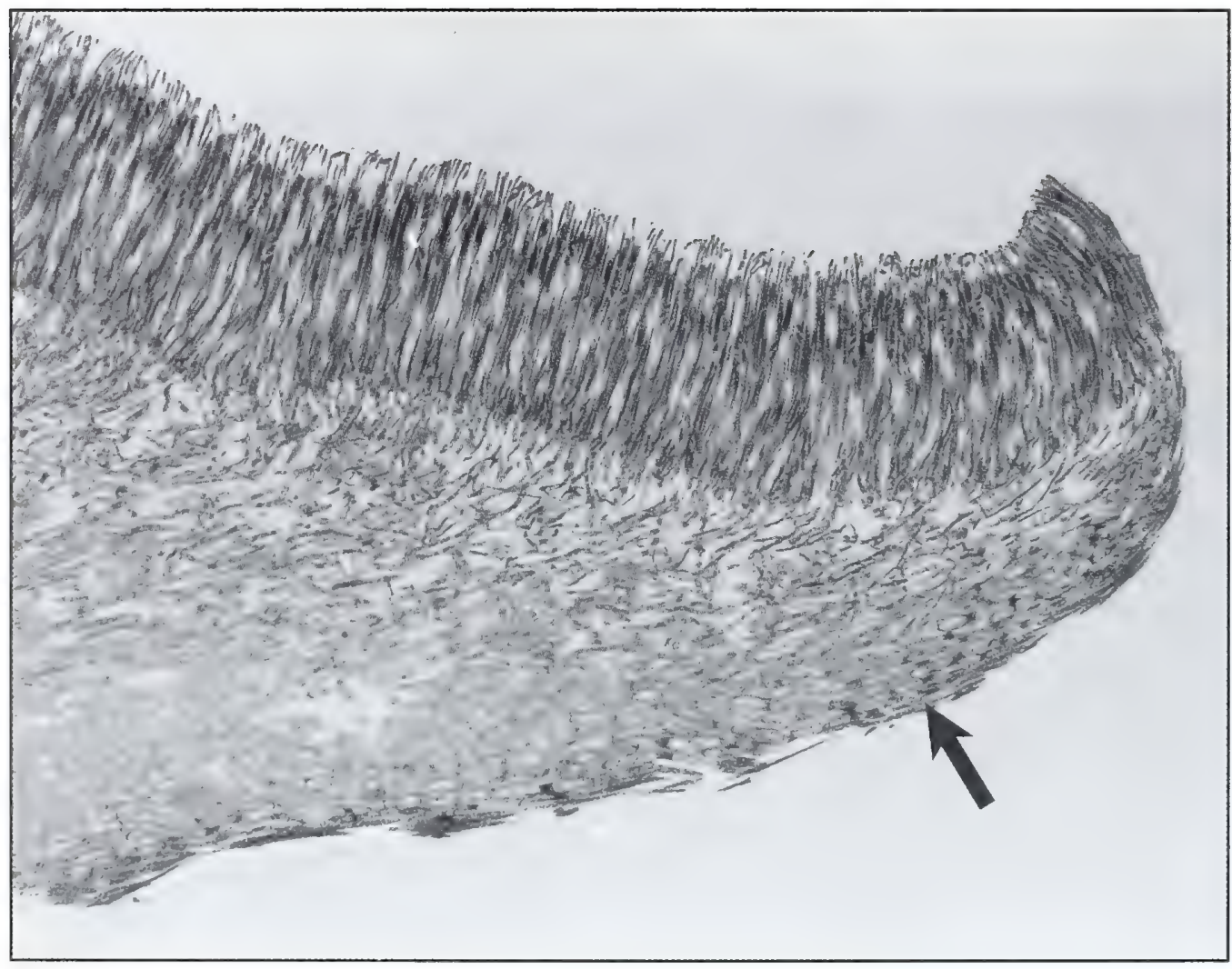

Figure 10. Cross section of apothecium of Gloeotinia temulenta. Arrow points to ectal excipulum. 


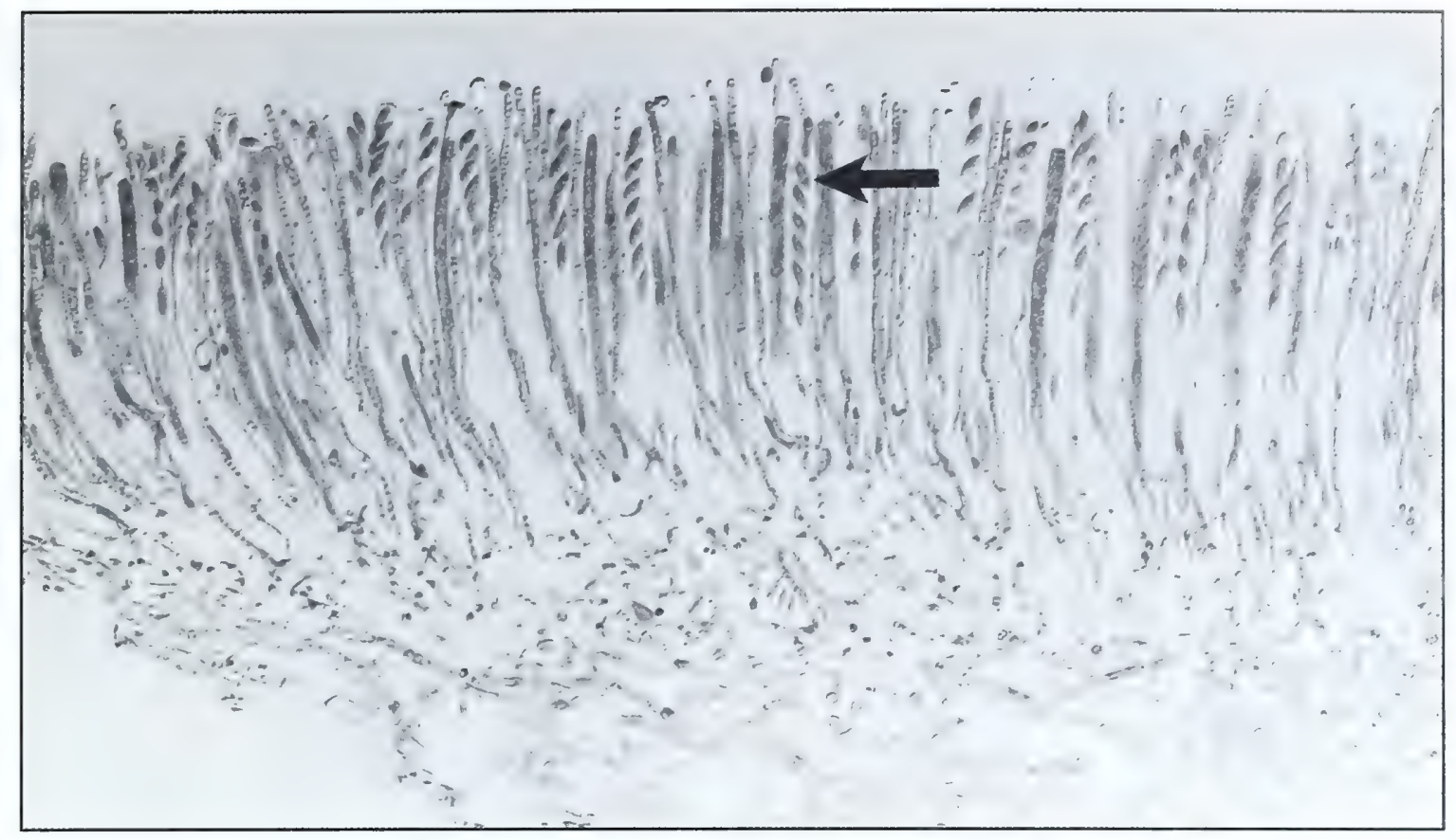

Figure 11. Cross section of apothecium of Gloeotinia temulenta. Arrow points to ascus.

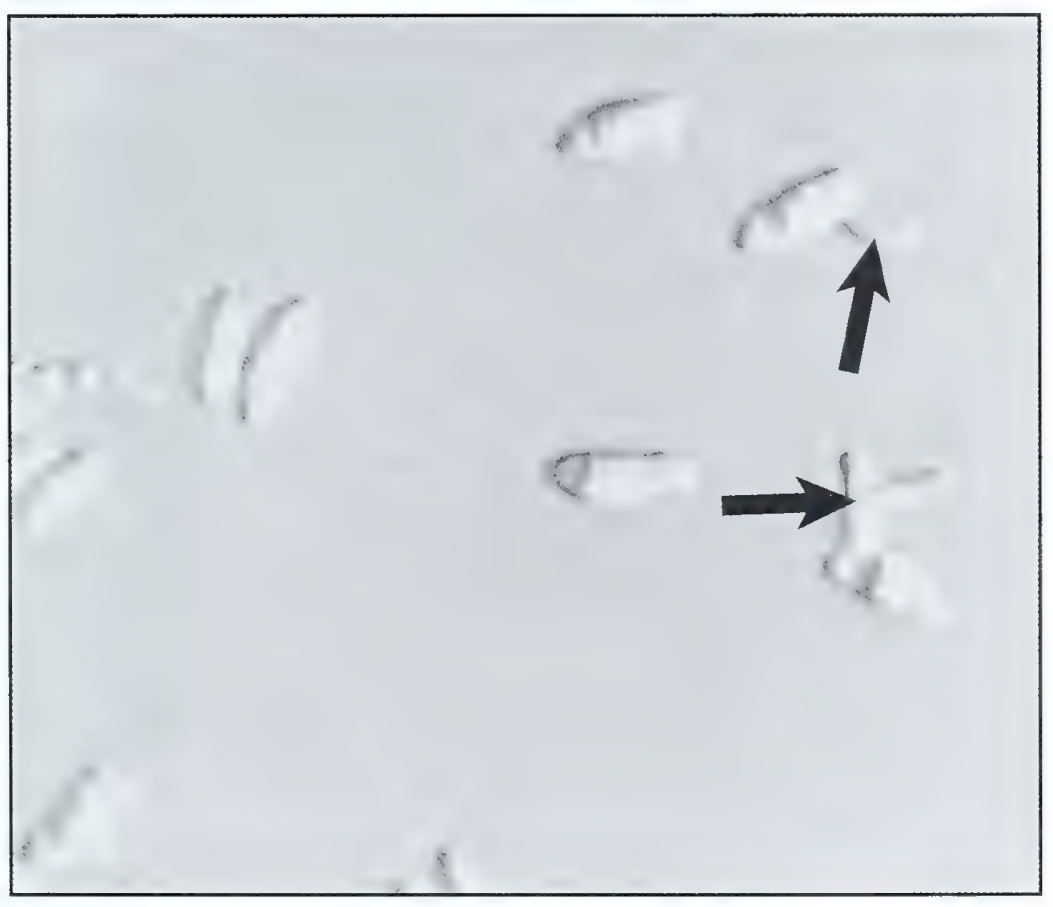

Figure 12. Germinating ascospores of Gloeotinia temulenta.

Arrow points to germ tube. 


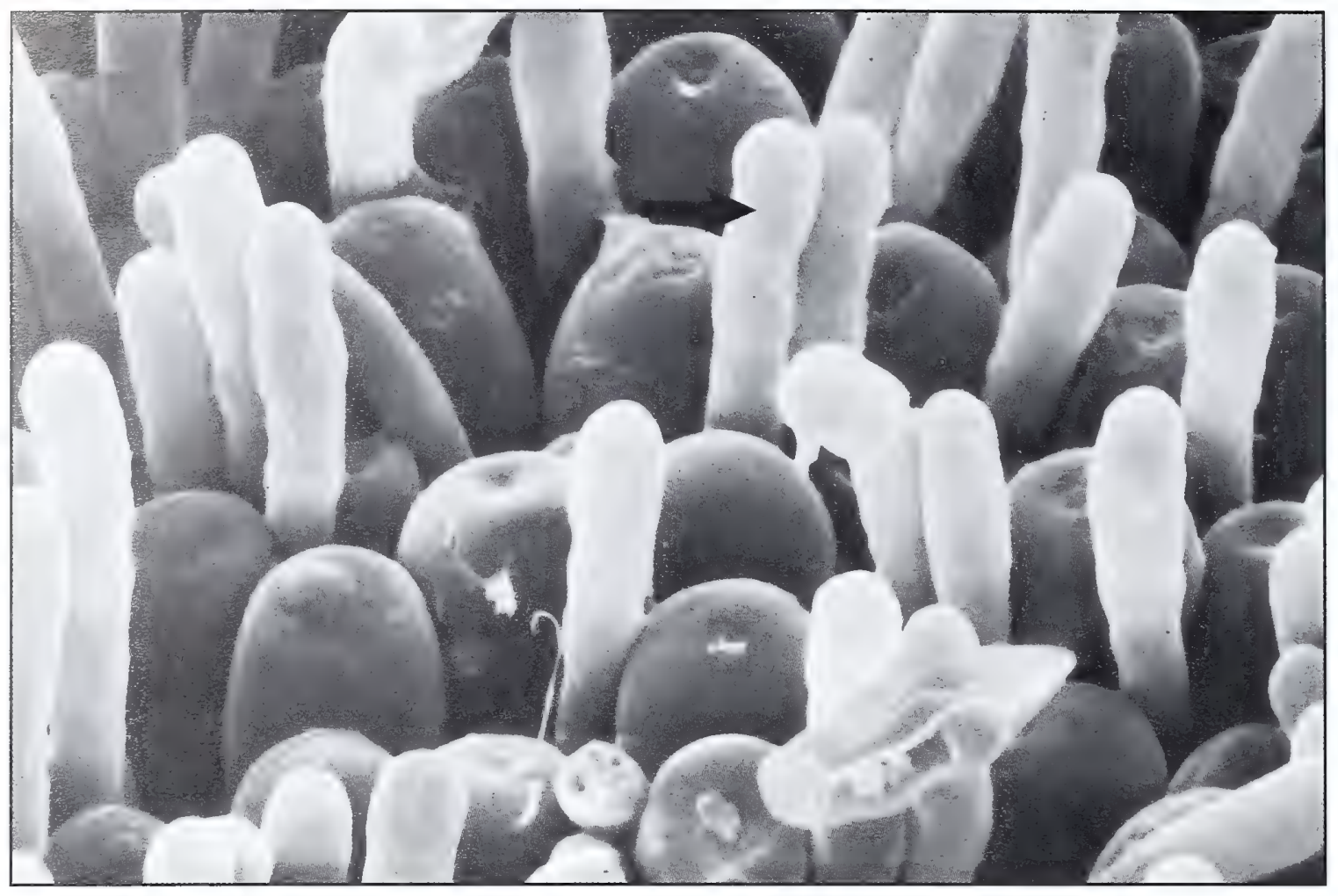

Figure 13. Surface of hymenium of Gloeotinia temulenta. Arrow points to paraphysis. 
addition of 1-percent peptone to PDA or malt agar increases spore mucilage production (Calvert and Muskett 1945). However, some cultures are predominantly mycelial while others are conidial (Wilson et al. 1945).

In culture, macroconidia are produced from short conidiophores formed at intervals perpendicular to the hypha (Calvert and Muskett 1945, Wilson et al. 1945). Conidia from culture may be larger (Wilson et al. 1945) or appear less regular than those from seed (Calvert and Muskett 1945). Growth is slow at $5{ }^{\circ} \mathrm{C}$, optimal at about $20^{\circ} \mathrm{C}$, less at $27^{\circ} \mathrm{C}$, and restricted at $30^{\circ} \mathrm{C}$ (Neill and Hyde 1939, Alderman 1992). Radial growth slows with decreasing water potential through -9.0 to $-1.0 \mathrm{MPa}$ (Alderman 1992).

Sporodochia develop in culture at $5{ }^{\circ} \mathrm{C}$ to room temperature after about 1-3 months (Calvert and Muskett 1945). Growth characteristics on various media were described by Neill and Hyde (1939) and Calvert and Muskett (1945).

\section{Similar-Looking Fungi}

Calvert and Muskett (1945) collected other discomycetes associated with ryegrass and detritus that are similar to $G$. temulenta but differ in morphology in culture and do not produce spores. Unfortunately, neither species identification nor technical descriptions of these other fungi were recorded.

Neill and Hyde (1939) found a fungus on Lolium that is similar to G. temulenta. They defined it as Lolium fungus number 2. Unfortunately, the taxonomic description and species identity of this fungus was not established either.

\section{Biology and Epidemiology Ovenwintering and Production of Apothecia}

The general life cycle of G. temulenta is illustrated in figure 14. The overwintering, or survival, unit of $G$. temulenta is the infected seed. Infected seeds reach the soil by shattering, by seed loss during harvest operations, by planting of diseased seeds, and by natural seed dispersal in harvested areas (Hardison 1945). Infected, ungerminable seeds resist attack by bacteria and molds and do not decay as they overwinter (Neill and Hyde 1939; Calvert and Muskett 1944, 1945). At or near the soil surface, $G$. temulenta continues to develop within the seed. Moist soil conditions with temperatures near $2{ }^{\circ} \mathrm{C}$ for about 8 weeks are required to induce the sexual (apothecial) stage of G. temulenta (Griffiths 1958). The precise biochemical changes that occur or metabolic pathways affected during this conditioning have not been determined.

In spring or early summer, at or prior to flowering of perennial ryegrass, apothecia emerge from the overwintering infected seeds (Calvert and Muskett 1945 , Wilson et al. 1945). Usually one to three, but as many as seven, apothecia can emerge from a single infected seed (Gray 1942, Calvert and Muskett 1945). Not all infected seeds will yield apothecia. In fact, only 5-30 percent of ungerminated seed produce apothecia (Calvert and Muskett 1945, Griffiths 1958).

\section{Production and Release of Ascospores (Primary Inoculum) and Primary Infection}

Large numbers of ascospores are ejected from each apothecium in response to slight changes in relative humidity (Calvert and Muskett 1945). In New Zealand, spore release occurs between early November and middle December, with peak numbers coinciding with flowering in perennial ryegrass (Neill and Armstrong 1955). Most spores are airborne between 10:00 a.m. and 2:00 p.m. (Johnston et al. 1965).

Ascospores that land on flowers, including the stigma, ovary, or styles, will germinate and infect the host. However, seeds can be infected up to the time they reach their maximum size (Hyde 1937).

\section{Secondary Infection}

Within about 7 days (Hyde 1937, 1945; Wilson et al. 1945) to 16-17 days (Calvert and Muskett 1945) after inoculation, the conidial stage is manifest-a pinkish slime in which conidia are embedded. These spores are relatively short-lived, about 1 month (Cunningham 1941, Neill and Hyde 1942). However, a few conidia may survive as long as 4-6 months if stored under cool, dry conditions (Calvert and Muskett 1945).

\section{Disease Development and Spread}

Wet seasons, especially during anthesis in the grasses, are clearly supportive of blind seed infection (Foy 1927; Gorman 1940; Osborn 1947; Blair 1947, 1948; Lithgow and Cottier 1953; Chestnutt 1958; de Tempe 1966; Grant 1985). Based on field surveys in New Zealand, Lithgow and Cottier (1953) found that districts which produced ryegrass seed with high germination (low blind seed disease) had less than half the rain days during flowering than districts producing seed with low germination. Hardison 


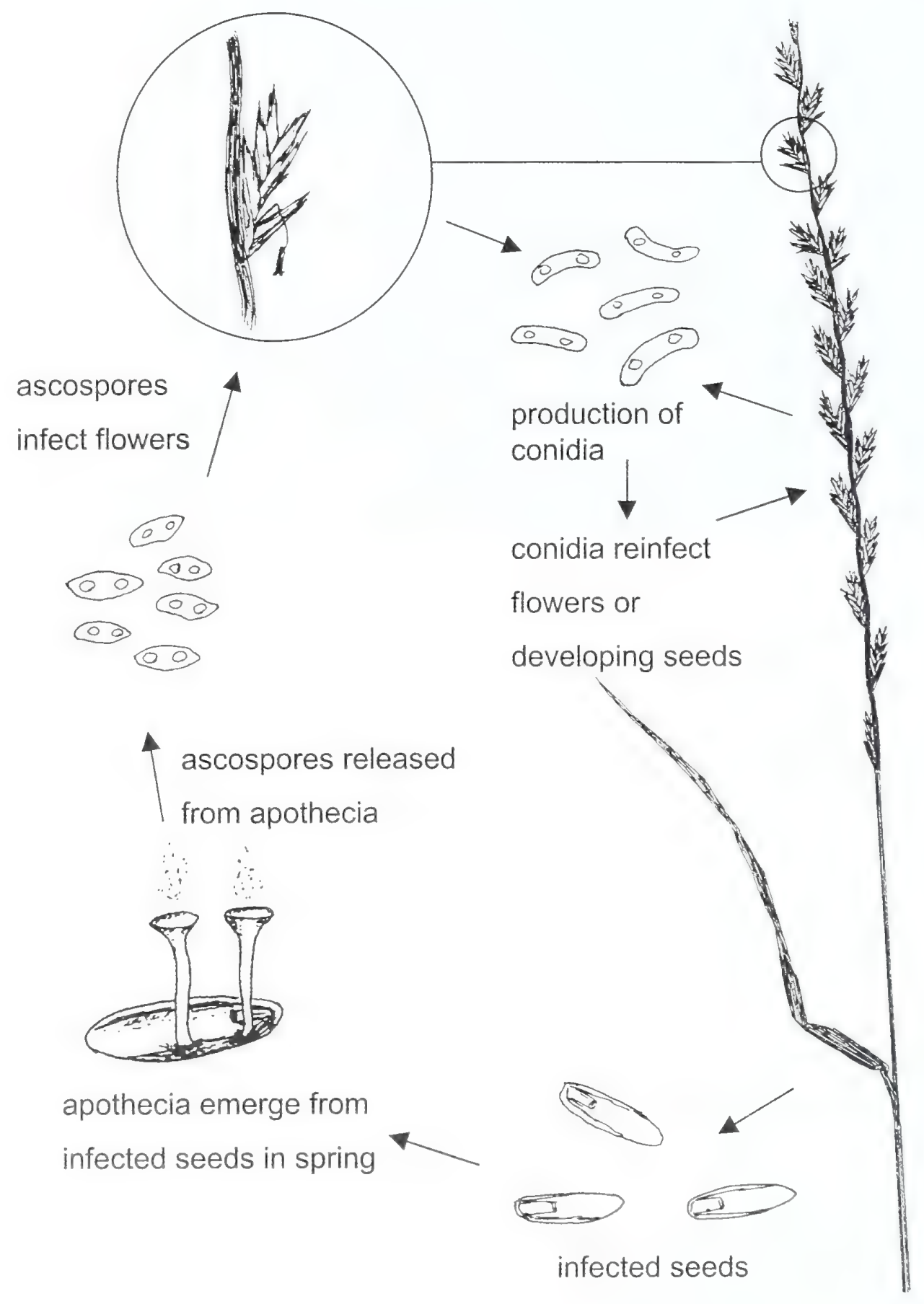

Figure 14. General life cycle of Gloeotinia temulenta. 
(1957) concluded that blind seed in Oregon was not present in inflorescences formed in fields after the regular harvest because postharvest conditions in Oregon are typically dry with little precipitation.

Large numbers of apothecia can appear during wet weather. Blair (1948) counted 20 apothecia per square foot and observed subsequent severe disease development during a wet season in New Zealand. Under the dry conditions of 1947, no apothecia were found, and subsequent disease development did not occur. Hardison (1963) estimated that under favorable conditions in Oregon, 100 pounds of severely infected seed dispersed per acre would be expected to yield 10-50 apothecia per square foot.

Wet seasons, combined with low temperatures, extend the period of apothecial production and spore release. However, not all apothecia are produced at the same time. Some apothecia develop early, others late. Under cool $\left(13{ }^{\circ} \mathrm{C}\right)$, wet conditions, apothecia can be produced over a 2-month time frame (Wright 1956). The expected lifespan of an individual apothecium is about 8-14 days, although they shrivel within a few hours in a dry atmosphere (Neill and Hyde 1939).

Temperatures of $10-16{ }^{\circ} \mathrm{C}$ and high humidity are considered ideal for blind seed development (Anonymous 1948, Alderman 1992). Infection does not occur under very warm $\left(30^{\circ} \mathrm{C}\right.$ ) temperatures (Alderman 1992).

Calvert and Muskett $(1944,1945)$ were the first to suggest that blind seed disease could spread from infested areas to noninfested areas, based on observations of commercial fields and field plots planted with pathogen-free seed. Additional sources of infection include seed for pastures (Hardison 1945), hedgerows with susceptible grasses, and waste ground (Calvert and Muskett 1945). Direct observations of spore movement were made by Neill and Armstrong (1955), who trapped spores of $G$. temulenta $18 \mathrm{~m}$ high and at ground level $1.6 \mathrm{~km}$ from the nearest infected field.

The highest rate of infection occurs while florets are open. The potential for infection reduces greatly after flowering (Calvert and Muskett 1944, 1945; Blair 1947). Corkill (1952) reported 90 percent infected seed when florets were open during inoculation, compared with 33 percent when florets were closed. Cool, moist weather conditions aid dispersal, prolong the period of pollination (Calvert and Muskett 1945), and extend the period of greatest susceptibility of the plant.

Flowering in a ryegrass spike begins at the top and progresses downward over about 10 days (Noble and Gray 1945). Production of conidia begins within 6 days of infection and increases for about 16 days (Alderman 1992). Consequently, infection of upper florets by windborne ascospores may result in the spread of subsequently produced conidia to lower florets (Noble and Gray 1945) under rainy conditions. Rain dissolves the slime in which conidia are embedded and provides a vehicle for their secondary spread (Neill and Hyde 1939, Calvert and Muskett 1945, Hyde 1945).

Calvert and Muskett (1945) speculated that insects may be involved with transmission of the condidial slime. However, no observations or data on association of Gloeotinia with insects or their ability to vector $G$. temulenta has been published.

Infections occurring at flowering or prior to endosperm formation resulted in seeds that are thin and light in weight (Neill and Hyde 1939, Hyde 1945). These infected seeds may not be capable of supporting apothecial production (Wilson et al. 1945), although they may support development of macroconidia (Hyde 1945). Abundant production of macroconidia during early flowering or seed development provides inoculum for secondary spread and subsequent disease development.

Seeds infected during the early to middle stages of development are approximately normal size and weight (Neill and Hyde 1939, Hyde 1945, Wilson et al. 1945), and a large quantity of spores are produced (Hyde 1945). Seeds infected late in development may be capable of germination (Wilson et al. 1940, Calvert and Muskett 1945, Hyde 1945, de Tempe 1950). Fewer spores are produced from late infections than from early ones (Hyde 1945).

The potential for rapid increase in blind seed severity was emphasized by Hardison $(1948,1957)$, who noticed a rapid increase in disease over a 1 - to 3-year period. De Tempe (1966) noted that seed with a 6.3 percent infection rate produced a crop with 26.7 percent seed infection. 


\section{Histopathology}

Detailed infection studies were conducted by Wilson et al. (1945) and Neill and Hyde (1939). Infections occurred at the base of the stigma in ovaries within 1 week of fertilization (Wilson et al. 1945). Hyphae invaded the inner epidermis, nucellus, and embryo sac. Within 9 days, conidia were produced between inner epidermis and outer integument and appeared on the surface. The endosperm and embryo filled with hyphae. The resulting grains were as long as healthy seeds but thinner. Hyphae invaded the embryo and endosperm when infections occurred after the embryo was differentiated into scutellum, plumule, radicle, and endosperm.

Neill and Hyde (1939) observed greater ramification and degradation of endosperm and embryonic tissues than Wilson et al. (1945), who observed extensive invasion of both embryonic and endosperm tissues. Wilson et al. (1945) observed hyphal penetration through the epithelial and aleurone layers, while Neill and Hyde (1939) reported that G. temulenta did not appear to penetrate cells of the aleurone layer. Systemic infections beyond the seed were not observed (Cunningham 1940, 1941; Neill and Hyde 1942; Wilson et al. 1945).

\section{Fungal Genetics and Physiology}

G. temulenta is heterothallic-it requires genetic exchange between two different mating types for sexual reproduction and subsequent production of apothecia (Griffiths 1958). G. temulenta has two mating types that are identical in all morphological features. Within each apothecium half of the ascospores are of each mating type, arbitrarily called "a" and "b." Apothecia will develop only after mating types $\mathrm{a}$ and $\mathrm{b}$ come into contact with one another and undergo fusion.

Conidia produced following infection from an ascopore of one mating type will produce only conidia of that mating type. Genetic exchange between types can occur through transfer of macroconidia from one infected seed to another or through transfer of microconidia, which can develop on the seed in spring after the seed has overwintered. A conjugation tube- $\mathrm{a}$ device to exchange genetic information - can form between pairs of macroconidia even before either conidium germinates (Wilson et al. 1945). As ex- pected from the heterothallic requirement of $G$. temulenta, relatively few infected seeds produce apothecia.

The vegetative hyphae are uninucleate. Chromosome number in G. temulenta is $\mathrm{n}=15$, and mitotic chromosomes range in size from 0.25 to $1.0 \mu \mathrm{m}$. (Griffiths $1959 \mathrm{~b})$. In the microconidiophores the nucleolus is lacking, RNA is low, and the level of RNA depends on the level in the subtending cells (Griffiths 1959a). Microconidia have not been observed to germinate and produce a vegetative mycelium but can serve a sexual function (Griffiths 1958).

Little is known about variability in virulence of $G$. temulenta. Sproule and Faulkner (1974) reported variation in aggressiveness among strains of $G$. temulenta. Wright and Sproule (1969) reported that disease ranking of clones was the same when mixed blind seed isolates from The Netherlands or the British Isles were used.

Little is known about the physiology of G. temulenta. A cold conditioning period of about 8 weeks is required to induce the apothecial phase. The metabolic pathways or mechanism associated with the induction have not been investigated.

\section{Toxicity}

Prillieux and Delacroix (1892a) and Prillieux (1897) described toxic properties associated with infection of rye by the asexual stage of the blind seed fungus, Endoconidium temulentum (anamorph of $G$. temulenta). Consumption of bread made from the flour induced dizzyness, faintness, vertigo, and an intensive stuporous state lasting for several days. Dogs, pigs, and poultry that consumed the bread became depressed, numb, and refused to eat or drink for 24 hours. The symptoms in humans and animals differed from those produced after ingestion of ergot (Claviceps purpurea) or darnal (Lolium temulentum) (Prillieux and Delacroix 1892a, Prillieux 1897). This is the only known report of toxicity from seed infected with $G$. temulenta.

Cunningham (1958) conducted trials in which sheep were fed seed infected with $G$. temulenta. No abnormal symptoms or effects were observed. 


\section{Disease Management}

The survival propagule of $G$. temulenta is the infected seed. Control measures center around removing as many infected seeds as possible from the field during harvest and avoiding introduction of infected seed by using disease-free or treated seed. Maintaining a healthy stand through good fertilization practices also contributes to control of blind seed. An integrated approach to blind seed control should consider disease resistance, field location, seed source, seed treatments, planting, time of closing, fertilization, stand density, fungicide sprays, methods of harvest, postharvest residue management (straw residue removal, postharvest plowing, crop rotation, field burning), and postharvest seed cleaning.

\section{Disease Resistance}

The search for resistance to blind seed began shortly after discovery of the disease. Early investigations in New Zealand compared indigenous grasses to commercial grasses (Hyde 1932, Calvert and Muskett 1944, Corkill and Rose 1945, Blair 1947). Differences in susceptibility were attributed to timing of flowering and favorability of climatic conditions during flowering (Gorman 1939, Gemmell 1940, Calvert and Muskett 1945, Corkill 1952, Wright 1956).

Early attempts at breeding ryegrass for resistance to G. temulenta were confounded by high variability and inconsistent results (Corkill 1952). Corkill and Rose (1945) examined progeny of crosses of resistant and susceptible ryegrass plants and concluded that resistance or susceptibility to the disease was inherited. Sproule and Faulkner (1974) reported that resistance was quantitative and repeatable across environmental conditions and fungal strains. Wright (1967) concluded that more than one gene was involved in resistance. Wright and Faulkner (1982) used a backcross program to introduce resistance to G. temulenta into S24 perennial ryegrass. Cultivars Calan and Logan were found to have significantly greater resistance than S24. Unfortunately, little resistance is believed to be present in most cultivars of perennial ryegrass and tall fescue now grown commercially for seed.

\section{Field Location}

Locating fields away from infested fields to avoid the introduction of inoculum from nearby sources is recommended (Blair 1947, 1948, 1952; Hardison 1949; Lithgow and Cottier 1953). To prevent estab- lishment and persistence of infected seed, grazed areas not kept for seed should be topped when seed heads appear (Blair 1948). Surrounding fields with crops such as cereals or root or forage crops may provide a barrier to movement of spores into a field (Blair 1947), although long-distance (more than $1 \mathrm{~km}$ ) airborne movement of ascospores can occur (Neill and Armstrong 1955).

\section{Seed Source}

Since infected seed is the source of inoculum, planting disease-free seed is recommended (Calvert and Muskett 1944; Blair 1947, 1948; Hardison 1949). Osborn (1947) and Blair (1948) suggested that in New Zealand supplies of disease-free seed could be obtained in dry years when little disease develops.

Prillieux (1897) reported that in France the disease was scarce on rye (Secale cereale L.), but recommended that, where the disease is present, seed from regions free of contamination be used for planting.

\section{Seed Treatments}

G. temulenta has limited survival in seed stored dry. Seed stored for 18 (Blair 1947), 21 (Calvert and Muskett 1945), or 20-22 months before spring planting (Hardison 1949, 1957) and 24 months before fall planting (Hardison 1949, 1957; Wade 1955) is considered safe to plant.

Calvert and Muskett $(1944,1945)$ controlled blind seed with a hot water treatment that included either a 4-hour pretreatment with tepid water, then 15 minutes at $50{ }^{\circ} \mathrm{C}$, or no preimmersion treatment and $30 \mathrm{~min}-$ utes at $50{ }^{\circ} \mathrm{C}$. The treatments provided full control with little or no reduction in seed germination. After hot water treatment, infected seeds decayed in the soil (Calvert and Muskett 1944). Untreated infected seeds resisted decay. De Tempe (1966) reported complete blind seed control with no effect on germination when seed was treated with water at $45-46{ }^{\circ} \mathrm{C}$ for $2-2$ CO hours. Gorman (1940), however, reported lack of adequate control from hot water treatments.

Numerous fungicides have been evaluated for their efficacy as seed treatments for blind seed disease. Although Hair (1952) reported some success, most of the early research indicated that chemicals applied as seed protectants were not effective against blind seed disease (Gorman 1940; Calvert and Muskett 1944. 1945; Blair 1947; de Tempe 1966; Hardison 1975). 
However, modern systemic fungicides such as benomyl have proven effective as a seed treatment (Hardison 1970. 1972; McGee 1971b). In New Zealand, seed treatment with fungicides has proven effective and is recommended for control of blind seed disease (Rolston and Falloon 1998).

\section{Planting}

Calvert and Muskett (1944) reported that seed samples from fields sown with a high level of blind seed did not on average show a higher rate of infection than seed from fields sown with disease-free seed. Similarly, de Tempe (1966) found no association between severity of blind-seed-infected seed at planting and subsequent level of infection at harvest. However, the effect of infected seed introduced at the time of planting depends on the method of planting and planting depth. Hardison (1957) observed that maximum production of apothecia occurred when fields too small for drill planting were planted by broadcasting seed over the soil surface. When seeds are planted more than one-half inch deep, apothecia have difficulty reaching the soil surface (Hardison 1949, 1957). Good preparation of the seed bed facilitates planting at the proper depth and good coverage of seed (Hardison 1949, 1963).

Fields with heavy soils or poor drainage may be more favorable for blind seed development because they provide the prolonged moist conditions that are favorable for production of ascospores. Good soil drainage provides conditions that are less favorable for apothecial production (Hardison 1949, 1963).

Infected seed must undergo a cool, moist period for about 8 weeks to induce the reproductive (apothecial) phase of the pathogen. Wright (1956) found that when seed was planted in spring, apothecial production did not occur; the requirement for cold conditioning was not met. Similar results were reported by Fischer (1944), who detected no apothecia when seed was planted in spring but found 75.6 apothecia per square meter in fall-planted seed.

Planting a susceptible first-year companion crop such as $L$. temlentum is not recommended because of its potential to increase inoculum if seed becomes infected (Hardison 1949, 1957, 1963).

\section{Time of Closing (Grazing)}

Crops in New Zealand that are closed to grazing very early or very late in the season may yield a crop that escapes peak ascospore dispersal (Blair 1947). Early closing was recommended in New Zealand by Gorman (1940), Lithgow and Cottier (1953), and Lynch (1952).

\section{Nitrogen Fertilization}

Numerous studies indicate a reduction in blind seed in response to manure or nitrogen fertilization. Chestnutt (1958) and Rutherford (1956) reported a significant reduction in blind seed in manured plots, compared with unmanured plots of perennial ryegrass. Lynch (1952) and Lithgow and Cottier (1953) observed that nitrogen improved yield and germination, although the effect of nitrogen on blind seed was uncertain. In a paired-plot experiment, Stewart (1963) found blind seed levels decreased in plots treated with nitrogen compared with untreated plots.

Hampton and Scott (1980a) established that a decline in blind seed between 1960 and 1980 in New Zealand correlated with the increased use of nitrogen fertilizer. In field trials, they demonstrated that as nitrogen rate increased, the rate of blind seed infection decreased, a result also reported by Hampton (1987) and de Filippi et al. (1996).

Under laboratory conditions, Hampton and Scott (1980a) observed that urea directly suppressed apothecial formation. However, in field plots, Hampton and Scott (1981) found no significant differences in number of apothecia among field plots treated with various levels of urea, although a reduction in blind seed infection was observed in urea treatments. They concluded that nitrogen fertilization altered the physiology of the plant, enhancing resistance to $G$. temulenta (Hampton and Scott 1980b).

In subsequent studies de Filippi et al. (1996) examined the level of blind seed in adjacent irrigated and nonirrigated field plots to which various rates of urea had been applied. In irrigated field plots, nitrogen application significantly reduced blind seed disease, but this did not occur in nonirrigated plots. As the inoculum source was external to the trial, they concluded that plants which are able to utilize available nitrogen develop a greater capacity to resist blind seed. The mechanisms associated with this resistance need to be determined.

Hampton (1987) reported there was no advantage to a split application of nitrogen (fall, spring) and recommended that all nitrogen be applied in spring. Blind 
seed levels in the study were lowest when all of the spring nitrogen was applied at spikelet initiation.

In addition to increasing resistance, nitrogen applications can also increase lodging or increase stand density, providing a physical barrier to restrict spore movement up through the canopy (Gorman 1940, Noble and Gray 1945, Blair 1947).

\section{Stand Density}

Movement of ascospores upward through ryegrass stands is believed to be reduced in a dense canopy, in stands that lodge, or where clover is planted with the ryegrass (Gorman 1940, Noble and Gray 1945, Blair 1947). Hampton (1987) reported that as lodging increased, blind seed disease decreased.

Lynch (1952) and Lithgow and Cottier (1953) found no evidence that germination was related to crop density or the extent of bottom growth, although they noticed improved germination in crops that lodged or those with increased percentages of grass in the sward. Wilson et al. (1945) observed that a ryegrass crop which remains standing until harvest was more likely to become infected by $G$. temulenta than a dense, heavily lodged crop. Noble and Gray (1945) found that acidic soils could contribute to poor stands of ryegrass and recommended replacement of ammonium sulfate with nitro chalk.

\section{Fungicide Sprays}

Under field conditions, fungicides applied as foliar or inflorescence sprays were not demonstrated effective in blind seed control by Corkill and Rose (1945), Hair (1952), or Hardison (1970). However, recent research from the Foundation for Arable Research (Rolston and Falloon 1998) has established that fungicides such as tebuconazole or carbendizim are effective for blind seed control in New Zealand.

Sprays applied as soil drenches or to the soil surface have been shown effective in reducing the number of apothecia. McGee (1971b) observed that benomyl applied at 2.8 and $5.6 \mathrm{~kg} / \mathrm{ha}$ reduced apothecia 80 and 90 percent, respectively. Hardison (1970) eliminated apothecia during April and May with a single application of benomyl $(4.5 \mathrm{~kg} / \mathrm{ha})$ applied the previous November, December, or January. Hardison (1972, 1975 ) lists other fungicides effective against $G$. temulenta under greenhouse conditions.

\section{Harvest}

Since the primary source of inoculum is the infected seed, early harvest to avoid excessive seed shatter is recommended. Osborn (1947) suggested early harvest under dry conditions as a source of disease-free seed, since late season disease could develop with a change in the weather to wet conditions. In Oregon, there is a narrow window of time in which swathing can occur to avoid seed shatter and obtain optimum seed yields.

Removal of lightweight or infected seeds during harvest reduces inoculum left in the field. Hardison $(1949,1957,1963)$ recommends adjusting combines to retain lightweight seeds for removal from fields.

\section{Straw Residue Removal}

Since dry soil conditions are unfavorable for apothecial development and spore release, Hardison (1949) recommended removing the straw after harvest to allow the soil surface to dry more rapidly in spring. In Oregon, residue is commonly baled and removed from the field. In some cases the straw is finely chopped with specialized flails. Residues that are not sufficiently chopped decompose slowly and can interfere with crop growth or development and may leave the soil wet for prolonged periods (Young et al. 1992).

\section{Postharvest Plowing}

Plowing infested fields reduces the area of infestation by burying much of the inoculum source-the infected seeds (Hardison 1963). Hardison (1949) recommended plowing in Oregon before May 15 to prevent emergence of apothecia near the time of flowering in ryegrass. The effectiveness of plowing in control of blind seed in Oregon was demonstrated by Hardison $(1949,1957,1963)$.

\section{Crop Rotation}

Blair (1947) reported that less infection occurred in stands following 3-4 years of arable crops, suggesting that rotation with crops not susceptible to blind seed may provide a means to reduce inoculum within a field.

\section{Field Burning}

The effectiveness of field burning in control of blind seed was established by Hardison $(1949,1980)$. Excellent control of blind seed is achieved with postharvest field burning. For optimal control, the entire dry-straw residue should be open burned. Burning by propane flaming after residue removal 
(baling) is not as effective as open burning, since propane does not achieve the temperatures of opengrass burning (Johnston et al. 1996).

\section{Seed Cleaning}

Recleaning of seed lots is not very effective in reducing the level of blind seed (de Tempe 1966). Hampton et al. (1995) reported that cleaning to a higher seed weight by removing infected seeds improved germination for some seed lots with a high level of infection; but in lots with a low level of blind seed, cleaning simply removed small but viable seed. A relationship between seed weight and germination could not be established.

Since infected seed are present in screenings, destroying the screenings destroys the inoculum. Destruction of screenings infested with blind seed was advocated by Hardison (1949).

\section{Methods for Detection and Assessment Postharvest Disease Detection and Assessment}

Early methods of blind seed detection involved the direct observation of seed. Gemmell (1940) detected infection by looking for small pinkish spots on dehusked seed under a binocular microscope illuminated by direct light on a white background. At Lincoln College in New Zealand, the usual procedure was to place 100 paled seeds under magnification and examine them for infection (Blair 1947), although removing the lemma or palea to examine the caryopsis can be tedious. Sproule and Wright (1966) developed a manually operated apparatus to facilitate the removal of lemma and palea.

Infected seeds generally appear more opaque than healthy seeds. A diaphanoscope was used to differentiate infected and healthy seeds based on opacity (Noble 1939, Glasscock 1940, Hyde 1945, Muskett 1948). However, opaque seeds can also occur if the seed is weathered before threshing, in which case opacity increases due to pigmentation (Gemmell 1940, Calvert and Muskett 1945, Muskett 1948).

For estimation of total infection, Hyde (1945), Blair (1947), and Matthews (1980) believed that direct observations were not as reliable as placing seed in water and looking for spores under the microscope. A magnification of 1003 is suitable for examination for conidia of G. temulenta (Calvert and Muskett 1945). The lemma and palea may be removed (Calvert and
Muskett 1945, Hyde 1945, Sproule and Wright 1966) or left intact (Kolk and Rennie 1978). Kolk and Rennie (1978) soaked seed for 4 hours; Matthews (1980) soaked seed for at least 2 hours.

The number of seeds considered to provide an accurate estimate of rate of infection was reported as 100 (Calvert and Muskett 1945, Blair 1947, de Tempe 1966), 200 (Hyde 1945, Matthews 1980), or 500 (Muskett 1948). Matthews (1980) referred to the soaking and examination of seed as the "soaking test." Matthews also performed a "droplet test," in which 100 seeds were individually soaked in drops of water on microscope slides for at least 4 hours. The drops were examined at 1003 and classified subjectively as having light, moderate, or heavy spore concentration. However, Matthews did not find a significant correlation between the droplet test and ungerminated seed.

Rose (1945) correlated conidial numbers removed through soaking samples of 100 seeds with germination rate, but high variability in the number of conidia prevented accurate prediction of germination. Hardison (1957) mixed $18 \mathrm{ml}$ of seeds and $18 \mathrm{ml}$ of water in 250-ml flasks, soaked the seeds for 20 minutes, then counted conidia in a $0.0063-\mathrm{mm}^{3}$ hemacytometer chamber. The number of conidia per $0.0063 \mathrm{~mm}^{3}$ corresponded to five infection classes ranging from trace to heavy. One to three conidia per $0.0063 \mathrm{~mm}^{3}$ corresponded to a trace infection level, and more than 30 conidia corresponded to a heavy infection. Alderman (1999) used a similar seedwashing procedure and established a linear relationship between the number of conidia washed from a standardized seed sample and the percentage of infected seed.

Matthews (1980) described a detection method based on production of apothecia. In this test, 200 seeds were scattered over moist perlite in 14-cm-diameter petri dishes. The dishes were placed in plastic bags and stored at $5{ }^{\circ} \mathrm{C}$ for 12 weeks. Normal germinated seeds were removed. Dishes were transferred to $20^{\circ} \mathrm{C}$ under a 12 hour light/ 12 hour dark cycle for a further 4-5 weeks. Seeds with apothecia were recorded. This procedure estimates the potential inoculum from seed, but since many infected seeds do not produce apothecia, the total number of infected seeds is greatly underestimated.

The number of seeds infected with viable $G$. temulenta can be assessed by isolating the pathogen 
on nutrient media. In this test, the palea are removed from the seeds, the caryoposis is surface sterilized and bisected, and the halves are plated on malt-extract agar (Neill and Hyde 1942, Calvert and Muskett 1945, Muskett 1948).

\section{Preharvest Testing}

Preharvest testing of blind seed was common during the 1940s in New Zealand (Scott 1974) to determine if the ryegrass seed crop should be harvested. Greenall (1943) sampled seed heads 2 weeks before harvest and found good correlation between the percentage of seed not infected (healthy seed) and germination of machine-dressed seed. However, samples should be taken within 1 week of cutting (Hyde 1942, 1945; Lithgow and Cottier 1953; Munro 1978; Alderman 1988, 1991b). Infection can occur up to the time of cutting, so samples collected too early could underestimate postharvest infection levels.

The number of seed heads believed to be representative of the area was reported as 50 (Wade 1949), 300 (Hyde 1945, Osborn 1947), or 400-500 (Lithgow and Cottier 1953; Alderman 1988, 1991b).

\section{Outlook}

The past decade has seen considerable changes in the management of grass seed as growers moved away from open-field burning of postharvest residue.
Current management practices generally include baling and removing straw residue followed by flail chopping any remaining residue. In some cases, specialized flail choppers are used on the full straw load. Some growers practice no-till planting. It is not clear what long-term effect these practices will have on development of blind seed disease. Weather's role is significant. Several consecutive years of wet weather during flowering could be highly favorable for disease development.

Surveys of blind seed disease conducted over the past decade have established the presence of a low level in Oregon. The recent appearance of a high level of blind seed in some fields of tall fescue indicates the potential for development of the disease. The greatest risk will come from residue management practices that leave large numbers of seeds in the field. Practices such as field cleaning or late harvesting in which considerable seed shatter occurs will only encourage the disease under favorable conditions.

Although significant yield losses are possible, it is important to keep in mind that there can be a significant drop in seed value at relatively low levels of infection. Germination rates below 90 percent can significantly reduce the value of the crop. Thus, the presence of only 5 to 10 percent blind seed can hurt profits. 


\section{Table 1. Geographical and host distribution of Gloeotinia temulenta}

Agropyron cristatum (L.) Gaertn.: United States (Hardison 1962)

Agrostis canina L.: Northern Ireland (Calvert and Muskett 1944), United States (Hardison 1962)

Agrostis capillaris L. [= A. tenuis Sibth.]: United States (Hardison 1962, Alderman 1991a,b)

Agrostis exarata Trin. [= A. exarata Trin. var. monolepsis (Torr.) Hitchc.]: United States (Fischer 1944)

Agrostis gigantea Roth: New Zealand (Blair 1947)

Agrostis stolonifera L. [=A. alba L.; = A. palustris Huds.]: New Zealand (Blair 1947). Northern Ireland (Calvert and Muskett 1944), United States (Hardison 1962, Alderman 1991a,b)

Aira caryophyllea L.: United States (Fischer 1944)

Alopecurus geniculatus L.: United States (Fischer 1944)

Alopecurus pratensis L.: United States (Hardison 1962)

Arrhenatherum elatius (L.) Beauv. ex J. and C. Presl: United States (Hardison 1962)

Bromus carinatus Hook. and Arn.: United States (Hardison 1962)

Bromus inermis Leyss.: United States (Hardison 1962)

Bromus racemosus L.: United States (Fischer 1944)

Bromus rubens L.: United States (Hardison 1962)

Calamagrostis bolanderi Thurber in S. Watson [= Calamagrostis varia Bol. ex. Thurber]: Germany (SchmidHeckel 1988)

Cynosurus cristatus L.: New Zealand (Blair 1947), Northern Ireland (Calvert and Muskett 1944)

Cynosurus echinatus L.: United States (Fischer 1944)

Dactylis glomerata L.: United States (Hardison 1962)

Danthonia californica Boland: United States (Fischer 1944)

Deschampsia cespitosa (L.) P. Beauv.: United States (Fischer 1944, Hardison 1962)

Elymus elymoides (Raf.) Swezey [= Sitanion hystrix (Nutt.) J.G. Sm.]: United States (Hardison 1962)

Elymus glaucus Buckley: United States (Hardison 1962)

Elymus lanceolatus (Scribn. and J.G. Sm.) Gould [= Agropyron dasystachyum (Hook.) Scribn.]:

United States (Hardison 1962)

Elymus repens $($ L.) Gould [= Agropyron repens $($ L.) Beauv.; = Elytrigia repens $($ L.) Nevski]: Norway (Schumacher 1979), United States (Hardison 1962)

Elymus trachycaulus (Link) Gould ex Shinners [= Agropyron trachycaulum (Link) Malte]: United States (Hardison 1962)

Festuca idahoensis Elmer: United States (Hardison 1962)

Festuca nigrescens Lam. [ =F. rubra L. var. commutata Gaud.; = F. fallax auct. non Thuill.; =F .

rubra L. subsp. fallax auct. non (Thuill.) Nyman ]: New Zealand (Neill and Hyde 1942. Blair

1947), United States (Hardison 1962, Alderman 1991a,b)

Festuca ovina L.: Northern Ireland (Calvert and Muskett 1944), United States (Hardison 1962)

Festuca rubra L.: United States (Hardison 1962)

Festuca trachyphylla (Hackel) Krajina [= F. ovina var. duriuscula (L.) Koch]: United States (Hardison 1962)

Glyceria borealis (Nash) Batsch.: United States (Fischer 1944)

Holcus lanatus L.: New Zealand (Blair 1947), Northern Ireland (Calvert and Muskett 1944). United States

(Fischer 1944, Hardison 1962)

Hordeum marinum Hudson subsp. gussoneanum (Parl.) Thell. [= H. hystrix Roth]: United States

(Fischer 1944)

Hordeum murinum L. subsp. leporinum (Link) Arcang. [= Hordeum leporinum Link]: United States (Hardison 1962)

Hordeum vulgare L.: United States (Hardison 1962)

Lolium arundinaceum (Schreber) Darbysh. [=Festuca arundinacea Schreb.; = F. elatior L.]: New Zealand (Neill and Hyde 1942, Blair 1947), United States (Hardison 1962; Alderman 1988, 1991a,b)

Lolium giganteum (L.) Darbysh. [= Festuca gigantea (L.) Vill.]: United States (Hardison 1962) 


\section{Table 1. Geographical and host distribution of Gloeotinia temulenta Continued}

Lolium multiflorum Lam.: Denmark (Lafferty 1948), Ireland (Lafferty 1948), Scotland (Noble and Gray 1945). New Zealand (Hyde 1938b, Lafferty 1948, Latch 1966), Northern Ireland (Calvert and Muskett 1944, 1945), United States (Hardison 1962)

Lolium perenne L.: Australia (Anonymous 1955, 1962; Wade 1957; McGee 1971a: Munro 1978), Denmark (Gemmell 1940, Lafferty 1948, Kristensen and Jørgensen 1960), England (Neill and Hyde 1939, Gemmell 1940, Glasscock 1940), Ireland (Gemmell 1940, Lafferty 1948), Netherlands (de Tempe 1950, 1966), New Zealand (Gorman 1939; Hyde 1942; Blair 1947, 1948; Lafferty 1948; Hampton and Scott 1980a; Neill and Hyde 1939, 1942), Northern Ireland (Neill and Hyde 1939. Calvert and Muskett 1944), Scotland (Neill and Hyde 1939, Gemmell 1940, Noble and Gray 1945, Dennis and Gray 1954), Sweden (Neill and Hyde 1939), United States (Fischer 1944; Hardison 1962; Alderman 1988, 1991a,b) and Wales (Neill and Hyde 1939)

Lolium pratense (Hudson) Darbysh. [= Festuca pratensis Huds.]: Northern Ireland (Calvert and Muskett 1944), New Zealand (Neill and Hyde 1942)

Lolium temulentum L.: New Zealand (Neill and Hyde 1942). United States (Fischer 1944, Hardison 1962)

Lolium temulentum L. subsp. remotum (Schrank) A. and D. Löve [= Lolium remotum Schrank]: United States (Hardison 1962)

Phleum pratense L.: United States (Fischer 1944, Hardison 1962)

Poa ampla Merr.: United States (Hardison 1962)

Poa arachnifera Torrey in Marcy.: United States (Hardison 1962)

Poa compressa L.: United States (Hardison 1962)

Poa nemoralis L.: United States (Hardison 1962)

Poa pratensis L.: New Zealand (Blair 1947), Northern Ireland (Calvert and Muskett 1944), United States (Hardison 1962, Alderman 1991a,b)

Poa secunda J. Presl subsp. juncifolia (Scribner) Soreng [= P. juncifolia Scribn.; = Poa nevadensis

Vasey ex Scribn.]: United States (Hardison 1962)

Poa trivialis L.: New Zealand (Blair 1947), Northern Ireland (Calvert and Muskett 1944), United States (Hardison 1962)

Psathyrostachys juncea (Fisch.) Nevski [= Elymus junceus Fisch.]: United States (Hardison 1962)

Pseudoroegneria spicata (Pursh) A. Löve [= Agropyron inerme (Scribn. and J.G. Sm.) Rydb.; = A. spicatum (Pursh) Scribn. and J.G. Sm.]: United States (Hardison 1962)

Secale cereale L.: France (Prillieux and Delacroix 1891), Germany (Rehm 1900). New Zealand (Neill and Hyde 1942), United States (Hardison 1962)

Thinopyrum intermedium (Host) Barkworth and D.R. Dewey [= Agropyron intermedium (Host) P. Beauv.; = A. trichophorum $($ Link) Richt.; = Elytrigia intermedia (Host) Nevskil: United States. (Hardison 1962)

Vulpia myuros (L.) C.C. Gmelin [= Festuca myuros L.]: United States (Fischer 1944. Hardison 1962) 


\begin{tabular}{|c|c|c|c|}
\hline Subfamily & Tribe & Species & $\begin{array}{l}\text { Relative } \\
\text { Infection }\end{array}$ \\
\hline
\end{tabular}

Arundinoideae

Danthoneae

Danthonia californica Boland

none

Pooideae

Aveneae

Agrostis canina L.

Agrostis capillaris L. [= A. tenuis Sibth.]

Agrostis stolonifera $\mathrm{L}$. [=A. alba $\mathrm{L} . ;=A$. palustris Huds.]

Aira caryophyllea L. var. capillaris (Host)

Mutel [= Aira elegans Willd. ex. Gaudin]

Alopecurus aequalis Sobol.

Alopecurus arundinaceus Poir. in Lam.

Alopecurus pratensis L.

Anthoxanthum odoratum L.

Arrhenatherum elatius (L.) Beauv. ex J. and C. Presl

Avena fatua $\mathrm{L}$.

Avena sativa $\mathrm{L}$.

Deschampsia cespitosa (L.) P. Beauv.

Holcus lanatus L.

Phalaris aquatica L. [= Phalaris tuberosa L.]

Phalaris arundinacea L.

Phleum pratense $\mathrm{L}$.

Trisetum flavescens (L.) Beauv.

Trisetum spicatum (L.) Richter

none to light

none to heavy

none to moderate

none

none

none

none to light

none

none to trace

none

none

none to trace

none to light

none

none

none to light

none

none

Poeae Cynosurus cristatus L.

none

Dactylis glomerata $\mathrm{L}$.

Festuca idahoensis Elmer

Festuca ovina L.

none to trace

none to heavy

none to heavy

Festuca rubra L.

Festuca rubra subsp. fallax Thuill $[=F$. rubra L. var. commutata Gaud.]

Festuca trachyphylla (Hackel) Krajina (= F.ovina var. duriuscula $($ L.) Koch)

Lolium arundinaceum (Schreber) Darbysh.

(= Festuca arundinacea Schreb.; $=F$. elatior $\mathrm{L}$.)

Lolium giganteum (L.) Darbysh. [=Festuca gigantea $($ L.) Vill.]

Lolium multiflorum Lam.

none to moderate

none to trace

light

light to heavy

Lolium perenne $\mathrm{L}$.

Lolium pratense (Hudson) Darbysh. $[=$ Festuca pratensis Huds.)

Lolium temulentum $\mathrm{L}$.

Lolium temulentum $\mathrm{L}$. subsp. remotum

(Schrank) A. and D. Löve (= Lolium remotum Schrank)

none to heavy

heavy

heavy

light

heavy

heavy 


$\begin{array}{lll}\text { Subfamily } \quad \text { Tribe } & \text { Species } & \begin{array}{l}\text { Relative } \\ \text { Infection }\end{array}\end{array}$

Poa ampla Merr.

Poa arachnifera Torrey in Marcy

Poa compressa $\mathrm{L}$.

Poa nemoralis L.

Poa palustris $\mathrm{L}$.

Poa pratensis L.

Poa secunda $\mathrm{J}$. Presl $[=P$. canbyi $($ Scribn.) Howell]

Poa secunda J. Presl subsp. juncifolia (Scribner) Soreng $[=P$. juncifolia Scribn.; $=P$. nevadensis Vasey ex Scribn.]

Poa trivialis L.

Vulpia myuros (L.) C.C. Gmelin [=Festuca myuros L.]

Triticoideae
Bromus arvensis $\mathrm{L}$.

Bromus carinatus Hook. and Arn.

Bromus catharticus Vahl

Bromus commutatus Schrad.

Bromus erectus Huds.

Bromus hordaeceus L. [= B. mollis L.]

Bromus inermis Leyss.

Bromus madritensis L.

Bromus marginatus Nees in Steud.

Bromus polyanthus Scribn. in Shear

Bromus rigidus Roth

Bromus rubens L.

Bromus secalinus L.

Bromus squarosus L.

Bromus tectorum L.

Triticeae
Aegilops cylindrica Host

Agropyron fragile (Roth) Candargy $[=A$. sibiricum (Willd.) P. Beauv,; = A. fragile (Roth) Candargy subsp. sibiricum (Willd.) Melderis]

Agropyron cristatum (L.) Gaertn.

Elymus canadensis L.

Elymus caninus (L.) L. [= Agropyron caninum (L.) Beauv.]

Elymus elymoides (Raf.) Swezey [= Sitanion hystrix (Nutt.) J.G. Sm.]

Elymus glaucus Buckley

Elymus lanceolatus (Scribn. and J.G. Sm.) Gould [= Agropyron dasystachyum (Hook.) Scribn.] trace to heavy

none to heavy

heavy

heavy

none

none to heavy

trace to heavy

light to heavy

none to heavy

light to heavy

none

none to trace

none

none

none

none

none to trace

none

none

none

none

none to trace

none

none

none

none

none

trace

none

none

trace

light

trace to light 


\begin{tabular}{|c|c|c|c|}
\hline Subfamily & Tribe & Species & $\begin{array}{l}\text { Relative } \\
\text { Infection }\end{array}$ \\
\hline & & $\begin{array}{l}\text { Elymus repens }(\mathrm{L} .) \text { Gould [= Agropyron } \\
\text { repens }(\mathrm{L} .) \text { Beauv.; = Elytrigia repens } \\
\text { (L.) Nevski] }\end{array}$ & trace \\
\hline & & Elymus sibiricus $\mathrm{L}$. & none \\
\hline & & $\begin{array}{l}\text { Elymus trachycaulus (Link) Gould ex } \\
\text { Shinners [= Agropyron trachycaulum } \\
\text { (Link) Malte] }\end{array}$ & trace \\
\hline & & $\begin{array}{l}\text { Elymus trachycaulus (Link) Gould ex } \\
\text { Shinners subsp. subsecundus (Link) } \\
\text { A. and D. Löve[= Agropyron } \\
\text { subsecundum (Link) A.S. Hitchc.] }\end{array}$ & none \\
\hline & & Hordeum brachyantherum Nevski & none \\
\hline & & Hordeum bulbosum $\mathrm{L}$. & none \\
\hline & & $\begin{array}{l}\text { Hordeum marinum Hudson subsp. } \\
\text { gussoneanum (Parl.) Thell. [= H. hystrix } \\
\text { Roth] }\end{array}$ & none \\
\hline & & $\begin{array}{l}\text { Hordeum murinum L. subsp. leporinum } \\
\text { (Link) Arcang. [= Hordeum leporinum } \\
\text { Link] }\end{array}$ & none to trace \\
\hline & & Hordeum vulgare $\mathrm{L}$. & none to trace \\
\hline & & $\begin{array}{l}\text { Leymus triticoides (Buckley) Pilg. } \\
\text { [= Elymus tritcoides Buckley] }\end{array}$ & none \\
\hline & & $\begin{array}{l}\text { Pascopyrum smithii (Rydb.) A. Löve } \\
\text { [= Agropyron smithii } \mathrm{Rydb} .]\end{array}$ & none \\
\hline & & $\begin{array}{l}\text { Psathyrostachys juncea (Fisch.) Nevski } \\
{[=\text { Elymus junceus Fisch.] }}\end{array}$ & none to heavy \\
\hline & & $\begin{array}{l}\text { Pseudoroegneria spicata (Pursh) A. Löve } \\
\text { [= Agropyron inerme (Scribn. and } \\
\text { J.G. Sm.) Rydb.; = Agropyron spicatum } \\
\text { (Pursh) Scribn. and J.G. Sm.] }\end{array}$ & trace to moderate \\
\hline & & Secale cereale $\mathrm{L}$. & none to heavy \\
\hline & & $\begin{array}{l}\text { Thinopyrum intermedium (Host) Barkworth } \\
\text { and D.R. Dewey [= Agropyron inter- } \\
\text { medium (Host) P. Beauv.; = A. trich- } \\
\text { ophorum (Link) Richt.;=Elytrigia inter- } \\
\text { media (Host) Nevski] }\end{array}$ & trace \\
\hline & & Triticum aestivum $\mathrm{L}$ & none \\
\hline
\end{tabular}

Source: Based on data from Hardison (1962). 


\section{References}

Alderman, S.C. 1988. Distribution of Gloeotinia temulenta, Claviceps purpurea, and Anguina agrostis among grasses in the Willamette Valley of Oregon in 1988. Journal of Applied Seed Production 6:6-10.

Alderman, S.C. 1991a. Assessment of ergot and blind seed diseases of grasses in the Willamette Valley of Oregon. Plant Disease 75:1038-1041.

Alderman, S.C. 1991 b. Distribution of Claviceps purpurea, Gloeotinia temulenta, and Anguina agrostis among grasses grown for seed in Oregon in 1989. Journal of Applied Seed Production 9:44-48.

Alderman, S.C. 1992. Influence of temperature and moisture on growth of Gloeotinia temulenta and infection of annual ryegrass. Phytopathology 82:196200 .

Alderman, S.C. 1996. Occurrence of Gloeotinia temulenta on tall fescue in Oregon. Plant Disease 80: 105.

Alderman, S.C. 1997. Gloeotinia temulenta and $G$. granigena, two separate species. Mycologia 90:422426.

Alderman, S.C. 1999. Recent occurrence and potential development of blind seed disease in Oregon. Journal of Applied Seed Production 16:7-10.

Anonymous. 1948. Research into blind seed disease of ryegrass. New Zealand Journal of Agriculture 77:609612.

Anonymous. 1955. Blind seed disease of ryegrass. In Report of the Waite Agricultural Research Institute, 1954-1955, University of Adelaide, South Australia, p. 29. Griffen Press, Adelaide, Australia.

Anonymous. 1962. New plant diseases. Agricultural Gazette of New South Wales 73:535-538.

Baral, H.O. 1994. On Drepanopeziza verrucispora and Symphyosirinia clematidis (Leotiales, Ascomycetes), with a key to the Symphyosirinia species. Zeitschrift für Mykologie 60:211-224.
Baral, H.O., and G.J. Krieglsteiner. 1985. Bausteine zu einer askomyzeten-flora der Bundesrepublik Deutschland: in süddeutschland gefundede inoperculate diskomyzeter - mit taxonomischen, ökologischen, chorologischen hinweisen und einer farbtafel. Zeitschrift für Mykologie 6:1-226.

Blair, I.D. 1947. Ryegrass blind seed disease. Canterbury Chamber of Commerce Agricultural Bulletin 210.

Blair, I.D. 1948. The elimination of ryegrass blindseed disease. In Proceedings of the Tenth Conference of the New Zealand Grassland Association.

Christchurch, November 23-24, 1948, pp. 8-9. New Zealand Department of Agriculture for the New Zealand Grassland Association.

Blair, I.D. 1952. Plant disease survey. In 26th Annual Report, New Zealand Department of Scientific and Industrial Research, p. 81. K.E. Owen, Government Printer, Wellington, New Zealand.

Boudier, E. 1907. Historie et Classification des Discomycetes d'Europe. Librairie des Sciences Naturelles, Paris.

Calvert, E.L., and A.E. Muskett. 1944. Blind seed disease of rye-grass. Nature 153:287-288.

Calvert, E.L., and A.E. Muskett. 1945. Blind seed disease of rye-grass (Phialea temulenta Prill. \& Delacr.). Annals of Applied Biology 32:329-343.

Chestnutt, D.M.B. 1958. Susceptibility of perennial ryegrass to blind seed disease. Journal of the British Grassland Society 13:275-278.

Corkill, L. 1952. Breeding for resistance to blind seed disease (Phialea temulenta, Prill. \& Delacr.) in ryegrass (Lolium sp.). In Proceedings of the 6th International Grassland Congress, August 17-23, 1952, pp. 1578-1584. Pennsylvania State College, State College.

Corkill. L., and R.E. Rose. 1945. Observations on susceptibility of perennial rye-grass to blind-seed disease. New Zealand Journal of Science and Technology $27: 14-18$. 
Cunningham, G.H. 1940. Plant disease investigations. In 14th Annual Report, New Zealand Department of Scientific and Industrial Research, p. 18. E.V. Paul, Government Printer, Wellington, New Zealand.

Cunningham, G.H. 1941. Plant disease investigations. In 15th Annual Report, New Zealand Department of Scientific and Industrial Research, p. 24. E.V. Paul, Government Printer, Wellington, New Zealand.

Cunningham, I.J. 1958. Non-toxicity to animals of ryegrass endophyte and other endophytic fungi of New Zealand grasses. New Zealand Journal of Agricultural Research 1:489-497.

de Filippi, J.M., J.G. Hampton, M.P. Rolston, and J.S. Rowath. 1996. Effect of nitrogen and irrigation on blind seed disease in perennial ryegrass (Lolium perenne L.) cv. Grasslands Nui. Journal of Applied Seed Production 14:81-83.

Dennis, R.W.G., and E.G. Gray. 1954. A first list of fungi of Zetland (Shetland). Transactions and Proceedings of the Botanical Society of Edinburgh $36: 214-223$.

de Tempe, J. 1950. De Phialea-ziekte van raaigras in Nederland. Tijdschrift over Plantenziekten 56:164169.

de Tempe, J. 1966. Blind seed disease of ryegrass in the Netherlands. Netherlands Journal of Plant Pathology 72:299-310.

Ellis, E.A. 1956. Symphyosirinia, a new genus of inoperculate discomycetes. Transactions of the Norfolk Norwich Naturalist's Society 18:1-17.

Fischer, G.W. 1944. The blind-seed disease of ryegrass (Lolium sp.) in Oregon. Phytopathology 34:934-935.

Foy, N.R. 1927. The official seed-testing station. Record of operations for 1926. New Zealand Journal of Agriculture 34:186-194.

Gemmell, A.L. 1940. The disease of ryegrass seed. West of Scotland Agricultural College Bulletin 136:316.

Glasscock, H.H. 1940. Blind seed disease of ryegrass. Nature 146:368-369.
Gorman, L.W. 1939. Low germination susceptibility of perennial rye-grass strains. New Zealand Journal of Science and Technology 20:392a-401a.

Gorman, L.W. 1940. Blind seed disease investigations. New Zealand Journal of Science and Technology $22: 79 a-83 a$.

Grant, A.S. 1985. A seed development study of the effects of different soil moisture regimes on three perennial ryegrass cultivars (Lolium perenne L.). Proceedings of the New Zealand Grassland Association 46:241.

Gray, E.G. 1942. Phialea mucosa sp. nov., the blindseed fungus. Transactions of the British Mycological Society 25:329-333.

Greenall, A.F. 1943. Low germination of perennial ryegrass seed in South Otago. New Zealand Journal of Agriculture 67:79-81.

Griffiths, E. 1958. Sexual reproduction and variation in Gloeotinia temulenta (Prill. \& Delacr.) Wilson \& Gray. Transactions of the British Mycological Society 41:461-482.

Griffiths, E.S. 1959a. Cytological and cytochemical aspects of the differentiation of the microconidia of Gloeotinia temulenta. Transactions of the British Mycological Society 42:123-124.

Griffiths, E. 1959b. The cytology of Gloeotinia temulenta (blind seed disease of rye-grass). Transactions of the British Mycological Society 42:132-148.

Hair, J.B. 1952. Blind-seed of ryegrass. III. Effect of fungicides on the disease. New Zealand Journal of Science and Technology 34:117-121.

Halfon-Meiri, A. 1978. Dangerous pathogens identified in imported seeds during the years 1965-1977. Phytoparasitica 6:40.

Hampton, J.G. 1987. Effect of nitrogen rate and time of application on seed yield in perennial ryegrass $\mathrm{cv}$. Grasslands Nui. New Zealand Journal of Experimental Agriculture 15:9-16.

Hampton, J.G., and D.J. Scott. 1980a. Blind seed disease of ryegrass in New Zealand. I. Occurrence and 
evidence for the use of nitrogen as a control measure. New Zealand Journal of Agricultural Research 23:143-147.

Hampton, J.G., and D.J. Scott. 1980b. Blind seed disease of ryegrass in New Zealand. II. Nitrogen fertilizer: effect on incidence, and possible mode of action. New Zealand Journal of Agricultural Research 23:149-153.

Hampton, J.G., and D.J. Scott. 1981. Blind seed disease of ryegrass in New Zealand. III. Urea: effect on apothecial production in the field and on blind seed infection - a note. New Zealand Journal of Agricultural Research 24:233-234.

Hampton, J.G., M.P. Rolston, N. Grbavac, et al. 1995. Germination in perennial ryegrass (Lolium perenne L.) seed lots from the 1993 New Zealand harvest. Journal of Applied Seed Production 13:66.

Hardison, J.R. 1945. Blind seed disease and plans for control. Proceedings of the Fourth Annual Meeting of the Oregon Seed Growers League, Eugene, Oregon, January 23-24, 1945, pp. 15-20.

Hardison, J.R. 1948. Field control of blind seed disease of perennial ryegrass in Oregon. Phytopathology 38:404-419.

Hardison, J.R. 1949. Blind seed disease of perennial ryegrass. Oregon State College Agricultural Experiment Station Circular 177.

Hardison, J.R. 1957. Record of blind seed disease control in Oregon. Plant Disease Reporter 41:34-41.

Hardison, J.R. 1962. Susceptibility of Gramineae to Gloeotinia temulenta. Mycologia 54:201-216.

Hardison, J.R. 1963. Control of Gloeotinia temulenta in seed fields of Lolium perenne by cultural methods. Phytopathology 53:460-464.

Hardison, J.R. 1970. Prevention of apothecial formation in Gloeotinia temulenta by benzimidazole compounds. Phytopathology 60:1259-1261.

Hardison, J.R. 1972. Prevention of apothecial formation in Gloeotinia temulenta by systemic and protectant fungicides. Phytopathology 62:605-609.
Hardison, J.R. 1975. Chemical suppression of apothecial formation in Gloeotinia temulenta. Plant Disease Reporter 59:229-231.

Hardison, J.R. 1976. Fire and flame for plant disease control. Annual Review of Phytopathology 14:355379.

Hardison, J.R. 1980. Role of fire for disease control in grass seed production. Plant Disease 64:641-645.

Höhnel, F.V. 1903. Mycologische Fragmente. Annales Mycologici 1:391-414.

Holst-Jensen, A., L.M. Kohn, and T. Schumacher. 1997. Nuclear rDNA phylogeny of the Sclerotiniacea. Mycologia 89:885-899.

Hyde, E.O.C. 1932. Germinating capacity of perennial rye-grass seed. New Zealand Journal of Agriculture 44:316-319.

Hyde, E.O.C. 1937. The present state of our knowledge concerning low germination in perennial ryegrass seed. In Papers Read at the Sixth Annual Conference of the New Zealand Grassland Association, Dunedin, August 10-12, 1937, pp. 90-96.

Hyde, E.O.C. 1938a. Detecting Pullularia infection in rye-grass seed crops. New Zealand Journal of Agriculture 57:301-302.

Hyde, E.O.C. 1938b. Germinating capacity of italian rye-grass seed. New Zealand Journal of Agriculture 56:357.

Hyde, E.O.C. 1942. Examination of ryegrass seed for blind seed disease. New Zealand Journal of Agriculture 65:349-350.

Hyde, E.O.C. 1945. Ryegrass seed. Preharvest examination for blind-seed disease and estimation of germinating capacity. New Zealand Journal of Agriculture $70: 271-276$.

Johnston. M.E.H., D. Matthews, and S.C. Harrison. 1965. The diurnal periodicity in the ejection of ascospores of Gloeotinia (Phialea temulenta (Pril. et Delacr.) Wilson, Noble, et Gray). New Zealand Journal of Agricultural Research 7:639-643. 
Johnston, W.J., C.T. Golob, J.W. Sitton, and T.R. Schultz. 1996. Effect of temperature and postharvest field burning of kentucky bluegrass on germination of sclerotia of Claviceps purpurea. Plant Disease 80:766-768.

Kolk, H., and W.J. Rennie. 1978. Report of the plant disease committee working group on grasses 1974 1977, Eighteenth International Seed Testing Congress. Seed Science and Technology 6:277-279.

Kristensen, H.R., and H.A. Jørgensen. 1960. New attacks of virus and fungi in Denmark 1957. Tidsskrift for Planteavl 64:610-613.

Lafferty, H.A. 1948. Blind-seed disease of rye-grass. Journal, Ireland Department of Agriculture, Dublin 45:192-201.

Latch, G.C.M. 1966. Fungous diseases of ryegrass in New Zealand. II. Foliage, root, and seed diseases. New Zealand Journal of Agricultural Research 9:808819.

Lithgow, A.V., and K. Cottier. 1953. Pre-harvest examination of ryegrass seed for blind seed disease. New Zealand Journal of Agriculture 87:405-406.

Lynch, P.B. 1952. Blind-seed disease of ryegrass. In Proceedings of the 14th Conference of the New Zealand Grassland Association, Nov. 25-28, 1952, Timaru, New Zealand, pp. 42-57. Wellington.

Matthews, D. 1980. A comparison of methods for the detection of blind seed disease (Gloeotinia temulenta) in ryegrass seed samples. Seed Science and Technology 8:183-191.

McGee, D.C. 1971 a. Blind seed of ryegrass (Gloeotinia temulenta). Victorian Plant Research Institute Report No. 6, p. 27. Department of Agriculture, Victoria, Australia.

McGee, D.C. 1971b. The effect of benomyl on Gloeotinia temulenta under laboratory and field conditions. Australian Journal of Agriculture and Animal Husbandry 11:693-695.

Munro, D. 1978. Ryegrass blind seed disease--pre harvest test. Tasmanian Journal of Agriculture 49: 192-193.
Muskett, A.E. 1948. Techniques for the examination of seeds for the presence of seed-borne fungi. Transactions of the British Mycological Society 30:74 83 .

Muskett, A.E., and E.L. Calvert. 1940. Blind seed disease of rye-grass. Nature 146:200-201.

Neill, J.C., and C.S. Armstrong. 1955. An aerial survey of ascospore distribution of blind-seed disease of ryegrass (Gloeotinia (Phialea) temulenta). New Zealand Journal of Science and Technology 34:106109.

Neill, J.C., and E.O.C. Hyde. 1939. Blind-seed disease of ryegrass. New Zealand Journal of Science and Technology 20:281a-301a.

Neill, J.C., and E.O.C. Hyde. 1942. Blind seed disease of rye-grass. II. New Zealand Journal of Science and Technology 24:65a-71a.

Noble, M. 1939. Notes of Pullularia pullulans in ryegrass seed and seed-testing methods as affecting detection of certain seed-borne diseases. Annals of Applied Biology 26:630-633.

Noble, M., and E.G. Gray. 1945. Blind seed disease of ryegrass. The Scottish Journal of Agriculture 25:94 97.

Osborn, W.L. 1947. Importance of blind seed disease in ryegrass. New Zealand Journal of Agriculture 75:595-601.

Prillieux, E. 1897. Maladies des plantes agricoles et des arbes fruitiers et forestiers. Tome second, pp. $453-$ 459. Maison Didot, Paris.

Prillieux and Delacroix. 1891. Endoconidium temulentum nov. gen., nov. sp. Prillieux et Delacroix, champignon donnant au seigle des proprietes veneneuses. Bulletin de la Societe Mycologique de France 7:116-117.

Prillieux and Delacroix. 1892a. Le parasite du seigle envirant. Bulletin de la Societe Botanique de France 13:168-169.

Prillieux and Delacroix. 1892b. Phialea temulenta nov. sp. Prillieux et Delacroix etat ascospore 
d'Endoconidium temulentum, champignon donnant au seigle des proprietes veneneuses. Bulletin de la Societe Mycologique de France 8:22-23.

Prillieux and Delacroix. 1893. Ciboria (Stromatinia) linhartiana forme ascospore de Monilia linhartiana, Sacc. Bulletin de la Societe Mycologique de France 9:196-200.

Quelet, M.L. 1883. Quelques espèces critiques ou nouvelles de la Flore Mycologique de France. In Les Champignons du Jura et des Vosges, pp. 387-412. Reprinted by A. Asher \& Co., Amsterdam, 1964.

Rehm, H. 1900. Ascomycetes exs. fasc. 27. Hedwigia 39:192-193.

Rolston, P., and R. Falloon. 1998. Blind seed control and seed yield increases in ryegrass. Foundation for Arable Research, Lincoln, New Zealand, Herbage Arable Update No. 16.

Rose, R.E. 1945. Germination and conidial number relationships in blind-seed disease. New Zealand Journal of Science and Technology 27:25-257.

Rutherford, A.A. 1956. The susceptibility of perennial ryegrass to blind seed disease. Journal of the British Grassland Society 11:66-70.

Schmid-Heckel, H. 1988. Pilze in den Berchtesgadener Alpen. Nationalpark Berchtesgaden, Forschungsbericht 15/1988.

Schumacher, T. 1979. Phialea granigena, an older name for Gloeotinia temulenta. Mycotaxon 3:125126.

Scott, D.J. 1974. Blind seed disease: preharvest testing to cease. New Zealand Journal of Agriculture 129:19.

Skipp, R.A., and J.G. Hampton. 1996. Fungus and bacterial diseases of pasture plants in New Zealand. In S. Chakraborty, K.T. Leath, R.A. Skipp, et. al., eds., Pasture and Forage Crop Pathology, pp. 213-236. American Society of Agronomy, Crop Science Society of America, and Soil Science Society of America, Madison, WI.

Spooner, B.M. 1987. Helotiales of Australasia:

Geoglossaceae, Orbiliaceae, Sclerotineacea, Hyaloscyphaceae. Bibliotheca Mycologica.
Sproule, T.R.M., and J.S. Faulkner. 1974. The reaction of eleven genotypes of Lolium perenne to British and New Zealand strains of Gloeotinia temulenta. Plant Pathology 23:144-147.

Sproule, T.R.M., and C.E. Wright. 1966. A rapid technique for the examination of large numbers of ryegrass samples for blind seed disease. Plant Pathology 15:180-183.

Stewart, R.H. 1963. Influence of nitrogen on the incidence of blind seed disease in S-24 perennial ryegrass. In Annual Report, Northern Ireland Ministry of Agriculture, Belfast, pp. 86-87.

Wade, G.C. 1949. Blind seed disease of ryegrass. Tasmanian Journal of Agriculture 20:226-228.

Wade, G.C. 1955. Seed treatment for disease control. Tasmanian Journal of Agriculture 26:42-46.

Wade, G.C. 1957. Diseases of pasture plants in Tasmania. Tasmanian Journal of Agriculture 28:6469.

Williams, M.A., and B.M. Spooner. 1991. Gloeotinia granigena. Mycopathologia 116:125-127.

Wilson, M., M. Noble, and E.G. Gray. 1940. Blind seed disease of ryegrass. Nature 145:783.

Wilson, M., M. Noble, and E.G. Gray. 1945. The blind seed disease of rye-grass and its causal fungus. Transactions of the Royal Society of Edinburgh 61(part II):327-340.

Wilson, M., M. Noble, and E. Gray. 1954.

Gloeotinia - a new genus of the Sclerotiniaceae. Transactions of the British Mycological Society 37:29-32.

Wright, C.E. 1956. Blind seed disease of ryegrass. II. A semi-natural field technique designed to test the blind seed disease reaction of paced ryegrass plants. The Research and Experimental Record of the Ministry of Agriculture (Northern Ireland) 6:4-13.

Wright, C.E. 1967. Blind seed disease of ryegrass. Euphytica 16:122-130.

Wright, C.E., and J.S. Faulkner. 1982. A backcross programme introducing resistance to blind seed 
disease (Gloeotinia temulenta) into the cultivar $\$ 24$ of the cross pollinated species perennial ryegrass (Lolium perenne). Record of Agricultural Research (Ministry of Agriculture for Northern Ireland) 30:45-52.

Wright, C.E., and T.R.M. Sproule. 1969. A comparison of the pathogenicity of Gloeotinia temulenta isolates from the United Kingdom and The Netherlands in relation to their use as selective agents in a breeding program. Plant Pathology 18:138-141.

Young, W.C., III, D.O. Chilcote, and T.B. Silberstein. 1992. An evaluation of equipment used by Willamette Valley grass seed growers as a substitute for openfield burning. Oregon State University Department of Crop and Soil Science, Ext/CrS 87.

Young, W.C., III, B.M. Quebbeman, T.B. Silberstein, and D.O. Chilcote. 1994. An evaluation of equipment used by Willamette Valley grass seed growers as a substitute for open field burning. Oregon State University Department of Crop and Soil Science,

Ext/CrS 99. 

